\title{
Salafiyya, Ahmadiyya, and European Converts to Islam in the Interwar Period
}

\author{
Umar Ryad
}

\section{Introduction}

The religious conflict between the Ahmadiyya Muslims and so-called "mainstream" Islam is as old as the establishment of this movement in India by Mirza Ghulam Ahmad (1835-1908) in the late nineteenth century. The heated debates that took place between the Ahmadis and other Muslims included both theological and political issues, such as the seal of the prophecy of the Prophet Muhammed, the claim that Ghulam Ahmad was the Promised Messiah, and the "collaboration" of the Ahmadiyya with British colonial authorities. ${ }^{1}$ In the interwar period the Ahmadiyya occupied a pioneering place as a Muslim missionary movement in Europe; they established mosques, printed missionary publications in a variety of European languages, and attracted many European converts to Islam. These converts played prominent trans-local, as well as transnational and transcultural roles in the development of modern Islamic thought in that era. Their new link with Islam should be seen as ingrained in the zeitgeist that inspired a few rich, mostly well-educated Europeans to adopt Islam as a new faith as a result of their search for spiritual pathways beyond their original culture and beliefs. In England, France, and Germany, many European converts became zealous in spreading Islam in Europe. ${ }^{2}$

The success of Ahmadiyya missionary work in interwar Europe reached the Muslim world and caused huge controversies among Muslim scholars, especially within the so-called Salafi reformist movement led by the well-known Muslim reformist scholar Muhammad Rashīd Riḍā (1865-1935) and popularized in his journal al-Manār [The lighthouse, 1898-1935]. We place these writers under the rubric "Salafiyya" because they approached Islam in the modern age by means of a reformist call to return to the early salaf (forefathers).

1 See, for example, H. Hanson, "Jihad and the Ahmadiyya Muslim Community: Nonviolent Efforts to Promote Islam in the Contemporary World," Nova Religio 11, no. 2 (2007): 77-93; Spencer Lavan, "Polemics and Conflict in Ahmadiyya History: The 'Ulema, the Missionaries, and the British (1898)," Muslim World 62, no. 3 (1972): 283-303.

2 Nathalie Clayer and Eric Germain (eds.), Islam in Interwar Europe (London: Hurst, 2008), 8-9.

(C) UMAR RYAD, 2016 | DOI 10.1163/9789004301979_004 
Although these Salafi groups had sectarian differences with the Ahmadiyya, there were also commonalities in terms of their discourse on Islamic reform and modernity. Amid these Salafi-Ahmadi doctrinal and sectarian divisions, news about the Ahmadiyya success in propagating Islam reached these circles (especially in Egypt) and put these Salafì writers in a quandary between their uncompromising sectarian differences with the Ahmadiyya and their desire to welcome the Ahmadiyya's success in converting Europeans to Islam.

Most of these Salafi writers were aware of the split within the Ahmadiyya movement, and that most of the work in Europe was achieved by the Ahmadiyya Anjuman-i Isha'at-i Islam (Ahmadiyya Society for the Propagation of Islam) under the leadership of Mawlana Muhammad 'Alī (1874-1951). Muhammad 'Alī was a sincere follower of Mirza Ghulam Ahmad and affirmed his position as a mujaddid (reformer), but not as a "Promised Mahdi or Messiah." Others also took this position: the Lahore mission in London, for example, was keen on distinguishing themselves from the Qadiyani branch of the Ahmadiyya led by Mirza Ghulam Ahmad's son in Qadiyan, who insisted that his father was the "Promised Messiah."

The historical role of the Ahmadiyya in the interwar period has been studied from the perspective of their local activities in Muslim communities in Europe. For example, the Woking Mission and mosque in South West London (established in 1914) became a "symbolic and organizational centrality in the inter-war period for British Islam,"3 when its first leader, the well-known Muslim lawyer Khwaja Kamal-ud-Din (1870-1932) set up a literary trust to publish their magazine and other missionary tracts. ${ }^{4}$ Through this mission, Islam appealed to many British figures, such as Baron Lord Headley (1855-1955) who founded the British Muslim Society in 1914, and Abdullah Yusuf Ali (1872-1953), a well-known translator of the Qur'ān, to name just a few. ${ }^{5}$ In April 1925, a "Lahori" mosque (i.e., aligned with the main Ahmadiyya) which was closely connected to the Woking mosque was established in Berlin. ${ }^{6}$ In 1924, the foundation stone for a Qadiyani mosque was laid in the Southfields suburb of London; the mosque was officially inaugurated in 1926. The Woking and Southfields mosques approached their propaganda in similar ways. In

3 See, K. Humayun Ansari, "The Woking Mosque: A Case Study of Muslim Engagement with British Society since 1889," Immigrants \& Minorities 21, no. 3 (2002), 7.

4 Eric Germain, "The First Muslim Mission on a European Scale: Ahmadi-Lahori Networks in the Interwar Period," in Islam in Inter-War Europe, ed. Nathalie Clayer and Eric Germain (London: C. Hurst \& Co., 2008), 89-91.

5 Ansari, "The Woking Mosque," 8.

6 See Gerdien Jonker's chapter in this volume. 
Germain's view, at the grassroots level the boundary between the two branches of the Ahmadiyya was somehow blurrred. Despite their competition, the Qadiyani mosque advertised the activities of the Lahori, and their newspapers had subscribers in common. In London, some people attended religious celebrations in Woking as well as in Southfields. This confusion was probably more convenient for the Qadiyani branch, since their work was still beginning in Europe. ${ }^{7}$

To a certain extent, the faith of the Lahore group in Ghulam Ahmad as a reformer made them less controversial than the Qadiyanis in some Salafi groups. It should be also emphasized that the Lahori Ahmadiyya missionaries in interwar Europe tried to down play these sectarian conflicts by adapting their message to their audiences in Europe on the one hand, and by seeking ways to present a positive image of themselves and their work in Europe to the Muslim public outside Europe. In 1929 James Thayer Addison described the Lahore group as more clever than sincere with regard to their origin, since they were

reluctant to admit any connection with the Ahmadiyya movement. Its leaders, especially in England, are eager to adapt their message to the convictions or the fashions of the present hour and to exploit the ignorance of their audience by making any assertions that will favor their cause. Intellectually more acceptable than the Qadiani, they inspire less respect, for one usually prefers the naive and narrow-minded to the sophisticated and slippery. ${ }^{8}$

In his well-documented work on British converts in the period from $185^{\circ}$ to 1950, Jamie Gilham gives a few local examples how British converts to Islam, who were engaged in the Ahmadiyya circles, reacted to sectarianism during that period. After World War I, early British converts repeatedly confirmed in their writings that the Ahmadiyya mission was part of the wider umma; but tensions about the Ahmadiyya differences and leadership began to appear again throughout 1930s. ${ }^{9}$ Around the same time, these conflicts reached the Muslim world. In addition to their involvement in the Ahmadiyya mission, during the interwar period European converts were active in a wider pan-Islamic

7 Germain, "The First," 102-103.

8 James Thayer Addison, "The Ahmadiya Movement and Its Western Propaganda," Harvard Theological Review 22, no. 1 (January 1929), 1.

9 Jamie Gilham, Loyal Enemies: British Converts to Islam 1850-1950 (London: Hurst, 2014), 200-205. 
Salafì network of associates, both inside and outside Europe. In particular, they took part in missionary work, in the translation movement of the Qur'àn in Europe, and in the Muslim intellectual and religious debates of that time. By such "transnational" connections, European converts were intermediaries, playing an "in-between" role between the European and Muslim cultures on the one hand, and between the Salafì reformist and the Ahmadiyya groups on the other. A deeper historical reading of these connections shows that despite their religious dissonance, the Ahmadiyya achievements in Europe and in relation to European converts created specific contact zones.

The position of European converts to Islam in the Salafi-Ahmadiyya disputes in the interwar period is remarkable. At the beginning of the 1930s, Muslim communities in India began an anti-Ahmadiyya campaign that included Ahmadiyya activities in Europe ${ }^{10}$ the debates that were generated had wide repercussions in various regions in the Muslim world and Europe. It is not surprising, given their reformist and puritan understanding of Islam, that the Salafiyya movement, in Cairo in particular, led one of the most outspoken anti-Ahmadiyya trends at the time. But, as we shall see, such negative attitudes were not always homogenous. On the one hand, we find that these Muslim reformists harshly attacked the Ahmadiyya doctrines, particularly their pacifistic view of jihad in Islam, but often praised their da'wa (missionary) activities in Europe on the other. We can also argue that the context of Muslims in Europe and the roles played by European converts to Islam sometimes obliged pan-Islamic reformist groups in interwar Europe to recognize and sometimes cooperate with the Ahmadiyya in serving common Islamic objectives.

In order to form a detailed picture of these conflicts, we highlight the attitudes of the Muslim reformist writers who contributed to Rashīd Riḍā's journal al-Manār and to the magazine al-Fath [The opening] founded by Riḍā's contemporary Syrian writer and activist Muhibb al-Dīn al-Khațib (1886-1969). Al-Fath, a weekly Islamic-oriented magazine, focused on the position of Islam and Muslim institutions in interwar Europe, especially on the work of European converts. Its editor can be considered among the Salafiyya because he supported the idea that Islam is not only restricted to ritual performance, but is a religion of "doctrine, worship, and rule." The magazine worked towards the removal of any "heretical elements" in the body of Islam. ${ }^{11}$ After Riḍā's death in

\footnotetext{
10 Germain, "The First Muslim," 103.

11 Amal N. Ghazar, "Power, Arabism and Islam in the Writings of Muhib ad-Din al-Khatib in al-Fath," Past Imperfect 6 (1997): 133-150·Also see Nimrod Hurvitz, "Muhibb ad-Din al-Khatib's Semitic Wave Theory and Pan-Arabism," Middle Eastern Studies 29, no. 1 (Jan.
} 
1935, al-Fath carried on Riḍā's legacy of the Salafiyya and flourished as a mouthpiece for many leading Salafī organizations and writers. However, as compared to Riḍā's "intellectual" Salafīsm, al-Fath carried this religious trend toward a more "populist" discourse. The activities of those European converts in their homelands were highlighted in a positive light by these journals in Egypt. Despite their adamant rejection of Ghulam Ahmad's "heterodox" theology, Salafĩ writers appreciated the religious work of the Ahmadiyya in interwar Europe and the conversion of many Europeans to Islam.

\section{Al-Manār and European Converts}

The conversion of European Christians to Islam was enthusiastically received by the early Salafiyya movement from the late nineteenth century on. They believed that Islam, unlike Christianity, could expand across the Muslim borders without any organized and collective missionary work. For example, Muhammad 'Abduh (1849-1905), the mufti of Egypt and Ridâ’s mentor, had direct contact with the prominent British convert Hajj Abdullah Browne (d. 1907). 'Abduh was impressed by Browne's "sincere worship and prayers," in English, which he found better than that of many who were born Muslim. ${ }^{12}$

Like 'Abduh, Ridā boasted about the conversion of Europeans to Islam. He saw their conversion as evidence of the failure of Christian missionary work in the Muslim world. ${ }^{13}$ He believed that most Muslims who abandoned Islam would never become real Christians, but rather turn into "atheists" or become antagonistic toward religion. Muslims mostly converted to Christianity out of poverty and need for financial support from missionaries, while in most cases western converts to Islam belonged to the elite classes in Europe. ${ }^{14}$

Riḍa was aware of the role of the Ahmadiyya's Woking mosque in converting Britons. Despite his positive tone regarding their work in Britain, al-Manār's strong anti-Ahmadiyya campaign never diminished. As early as 1901, Rị̣ā attacked Ghulam Ahmad for his claim to be a "shade for the Prophetic

1993): 118-134; Catherine Mayeur-Jaouen, "Les débuts d'une revue néo-salafiste: Muhibb al-Dîn al-Khatîb et Al-Fatḥ de 1926 à 1928," Revue des mondes musulmans et de la Méditerranée, 95-98 (April 2002), available online: http://remmm.revues.org/234.

Umar Ryad, "Islamic Reformism and Great Britain: Rashid Riḍās Images as Reflected in the Journal al-Manār in Cairo," Islam and Christian Muslim Relations 21, no. 3 (2010), 273.

13 Umar Ryad, Islamic Reformism and Christianity: A Critical Reading of the Works of Muhammad Rashid Rid̄a and his Associates (1898-1935) (Leiden: Brill, 2009), 166-169; Ryad, "Islamic Reformism and Great Britain," 271.

14 Ryad, Islamic Reformism and Christianity, 160, 168-170. 


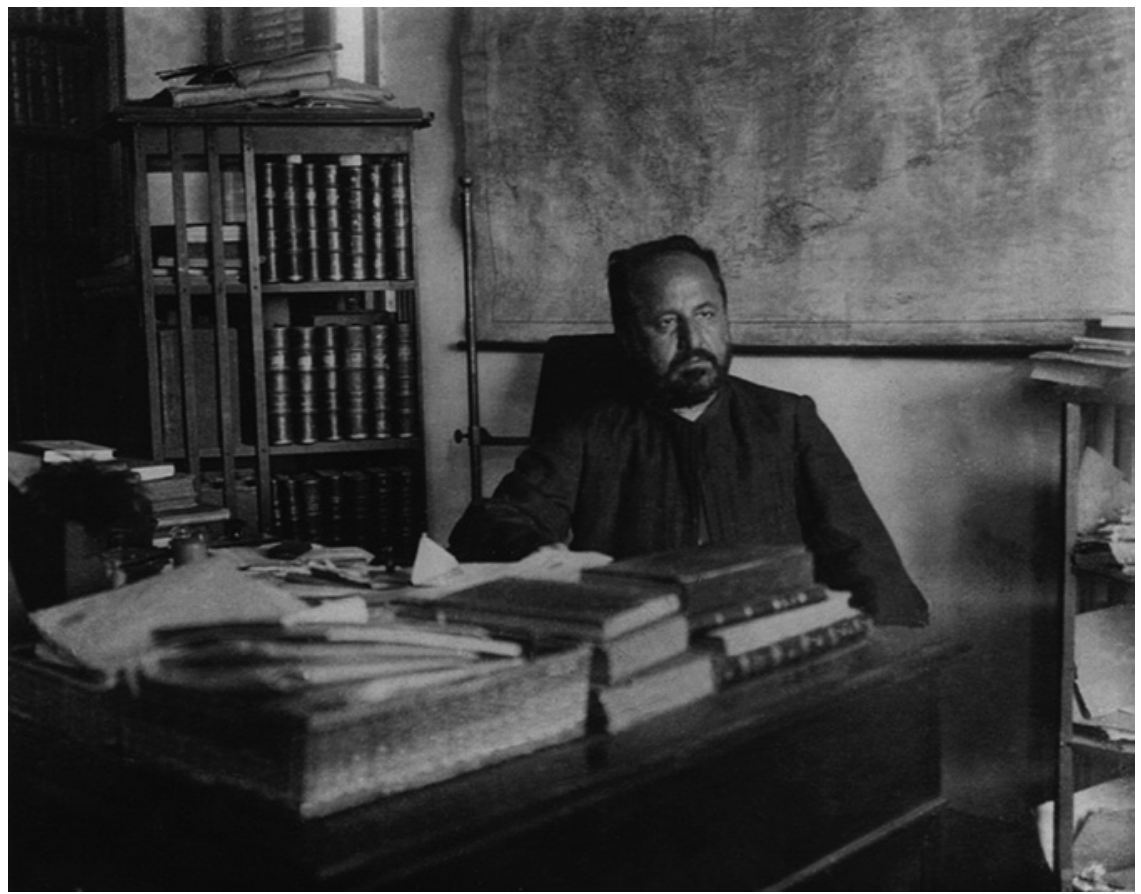

FIGURE 3.1 Sheikh Muhammad Rashìd Rid̄ā (1865-1935) in his Al-Manār Office in Cairo (Family archive in Cairo)

miracle."15 In response, Ghulam Ahmad depicted Riḍā as a "jealous" and "arrogant" scholar who, like many others, not only rejected the message, but fueled the dislike of Indian Muslims against him and his followers. ${ }^{16}$

15 See, Mirza Ghulam Ahmad, Ijāz al-masih (Tilford, Surrey, uk: al-Shirkat al-Islamiyya Limited, 2011), 34; available online: http://www.islamahmadiyya.net/pdf/ijaz_maseeh _full.pdf (accessed 20 March 2014); Rị̣ā wrote this in a fatwā to a question sent to al-Manār by a certain Aḥmad Muḥammad al-Alfī, a local Shafi'ì scholar in the town of Tukh in northern Egypt. Al-Manār, 4, no. 12 (31 Aug. 1901), 460-468.

16 Mirza Ghulam Ahmad, al-Hudā wa-l-tabșira liman yarā (Tilford, Surrey, uk: al-Shirkat al-Islamiyya Limited, 2011); available online: http://www.islamahmadiyya.net/books2. asp?book_key=67\&magazine =o (accessed 20 March 2014). also, al-Manār 5, no. 8 (22 July 1902), 317-320; al-Manār 5 no. 10 (20 Aug. 1902), 398-399. Cf. al-Manār 23, no. 1 (Jan. 1922), 33-35; al-Manār 31, no. 5 (Dec. 1930), 391-396; al-Manār 5, no. 19 (15 Jan. 1903), 789-791; also see al-Manār 24, no. 8 (Aug. 1923), 578-583; al-Manār 27, no. 1 (April 1926), 55-67. Also see the reactions of Mawlana Abu Wafa Sanaullah of Amritsar (1868-1948), one of the fiercest Indian opponents to Ghulam Ahmad, in al-Manār 27, no. 3 (June 1926), 238-239. 


\section{Cautious Appreciation: Lord Headley}

Despite harsh critiques of Ahmadiyya doctrines, al-Manār, in some instances, hailed the conversions of Europeans to Islam in the Woking mosque. The above-mentioned Baron Lord Headley and his conversion occupied a prominent place in al-Manār, despite Headley's known close connection with the Ahmadis in London.

Yet Headley's conversion was disputed in British society and Christian missionary circles, where it was seen as a form of "political Islam" because of his representation of Muslims in the House of Lords. Others claimed that he had not given up his former Christian beliefs completely, that in fact he maintained his faith in Jesus and his divine mission. ${ }^{17}$ Moreover, we know of two letters that Headley received from devout Christian friends who were shocked by his conversion to a religion "of sensuality and [in which] the Prophet had a great many wives."18

Many journals in the Muslim world became interested in these disputes regarding Headley's conversion to Islam. His response, "Why I became a Mohammedan," was fully translated into Arabic and published by al-Manār. In this response, Headley argued that "Islam and Christianity as taught by Christ himself are sister religions, only held apart by dogmas and technicalities which might be very well be dispensed with."19 In his comment on Headley's article, Ridā agreed with his "brother" Lord Headley that Islam is the Christianity which Jesus had called for. For Ridā, Headley's views resembled the response of Riḍā's pan-Islamic predecessor Jamāl al-Dīn al-Afghānī to the "failure" of Christian missions in India in the nineteenth-century when he said: "Islam is Christinaity with some additions." Islam confirms the same monotheistic faith and ethics that Jesus had called for, but invalidates what the Christians had

Ahmadiyya followers contended that the issue was unilateral and Mirza Ghulam Ahmad was not involved in this issue at all. See, for example, http://aaiil.org/text/acus/mga/ sanaullah.shtml (accessed 24 March 2014). See Riḍās debate with them during his stay in Lucknow (1912), al-Manār 31, no. 5 (Dec. 1930), 391-397; al-Manār 31, no. 6 (Jan. 1931), 479-480; al-Manār 31 no. 7 (Feb. 1931), 559-56o; al-Manār 31, no. 10 (July 1931), 751-752.

As quoted in al-Manār 17, no. 1 (Dec. 1913), 34-40. Cf. al-Manār 28, no. 7 (Sept. 1927), 543-550. About Headley's conversion in the western press, see, for example, "Irish Peer turns Moslem," New York Times (16 Nov. 1913), 1; "Mohammedan Peer," Observer (16 Nov. 1913), 13; "Irish Peer converted to Mohametanism," Manchester Guardian (17 Nov. 1913), 9. Al-Manār 17, no. 1 (Dec. 1913), 34-40. Cf. Lord Rowland George Allanson Headley, "Why I became a Mohammedan," Observer (23 Nov. 1913), 4. 
later "corrupted." Rị̣ā believed that Europeans of his age would find Islam suitable, as it is the religion of "reason," "science," "civilization," and "peace." There were a number of impediments to their conversions to Islam, including Muslim sectarian strife, political animosities, the deteriorating state of Muslims, and their own unfamiliarity with the truth of their religion. In addition to these obstacles among Muslims, the Europeans lacked knowledge regarding Islam, the Arabic language, and were influenced by materialist sciences and practices, and by Christian myths and the cruelity of Papacy's authority in the past. These all led to the prevalent European aversion to religion in general. Ridâ̄'s words also addressed "westernized" Muslims, who mistakenly thought that Europeans were atheists. ${ }^{20}$

In addition to his joy in Headley's conversion, an unknown reader of al-Manār in London, wrote under the name muslim ghayr mutafarnij (a nonwesternized Muslim) that he appreciated the religious work of the Woking mosque and their periodicals, The Islamic Review and Muslim India, that served the Islamic message. In a short time, the Woking mosque was able to convert a good number of Europeans, including Elinor Annie Saxby, Ernst W. Oaten, and Amina Bamford. This so-called non-westernized Muslim translated Amina Bamford's conversion account that had been published in The Islamic Review, and submitted the translation for publication in Ridâ's journal. This was another message to Europeanized Muslims who had decided to abandon their religious beliefs and practices after mixing with Europeans. ${ }^{21}$ This London reader of al-Manār wished that a Muslim prince or a rich man would finance Rị̣ā’s Islamic missionary school, Dār al-Da'wa wa-l-Irshād (founded in 1912), so that it could serve as a training college for young Muslim preachers committed to propagate Islam in Europe. ${ }^{22}$ In response to the doubts expressed by some Muslims about the sincerity of European converts and their adherence to religious duties such as prayer and fasting, he replied that the Europeans' knowledge was based on their own research and reading, and their negligence of Islamic duties was no less controversial than that of some who were born Muslims and also neglected their religious duties. In his view, the Europeans' conversions was a boon to Islam in the west. ${ }^{23}$ In his response, Ridā expected more from Indian Muslims than Egyptians, at least with regard to the task of Islamic propaganda in Europe. The majority of rich Muslims were, however, in

\footnotetext{
20 al-Manār 17, no. 1 (Dec. 1913), 34-40.

21 Ryad, "Islamic Reformism and Great Britain," 278-279.

22 Ibid.

23 Al-Manār 18, no. 1 (Feb. 1913), 73-75.
} 
his view, too "stupid" and "villainous" to fund public projects, except when such projects would raise their status in the eyes of rulers and princes. ${ }^{24}$

In general, Riḍa agreed with Khwaja Kamal-ud-Din's "friends" and followers in Egypt and considered him a "moderate" follower of the Ahmadiyya. In 1923, Lord Headley, Kamal-ud-Din, and Abdul Mohye, the Arab mufti of the Woking Mosque (the Arab press gave him the title of the Mufti of the English Lands), passed through Egypt on their way to hajj. The trip was covered in a favorable light in the Islamic press in Egypt, including al-Manār. In Egyptian newspapers, Kamal-ud-Din found a suitable opportunity to defend the Lahore branch of the Ahmadiyya and their faith as being a trend close to "mainstream" Islam. Ridā was not able to meet them in order to discuss his doubts regarding the Ahmadiyya with Kamal-ud-Din in person. At this point, Riḍa found that Kamal-ud-Din's consideration of Ghulam Ahmad as merely a "reformer" was a good step by the Lahore branch towards the "true" Islam. ${ }^{25}$

Headley and his fellow pilgrims were highly regarded during this visit. Reception committees were organized in Port Said, Cairo, and Alexandria in order to honor Lord Headley in particular. From Port Said to Cairo and Alexandria, large gatherings appeared in train stations:

everywhere people would shake hands with Lord Headley and reverentially kiss the Khwaja's hands. Young and old joined together in lusty cheers of "Long live Lord Headley!" and "Long live Khwaja Kamal-udDin!" At such of the stations where stoppage was not less than three or four minutes the guests would speak a few words... ${ }^{26}$

In the Cairo railway station, a huge crowd gathered to welcome the guests. Headley and his friends were guests at the Heliopolis residence of the Egyptian notable and Sufi Sayyid Iḥsān al-Bakrī, who was well known to most English Muslims because of his stay in England and interest in the Woking mission activities. After the Friday prayer at al-Husayn Mosque, prayers and speeches were made in honor of the British Muslims by religious scholars and other notables, including Shaykh al-Sāwī, the president of the Cairo reception committee and the Naqīb al-Ashrāf (head of the descendants of the Prophet). A dinner banquette was organized for five hundred people that evening. Similar meetings were also organized in Alexandria, where Headley and his fellows

\footnotetext{
24 Ryad, "Islamic Reformism and Great Britain," 278-279.

25 Al-Manār 24, no. 8 (Aug. 1923), 583.

26 "Khwaja Kamal-ud-Din and Lord Headley in Egypt," Islamic Review (Sept. 1923), 301-307.
} 
were welcomed by religious scholars, merchants, politicians, and notables including the Egyptian prince 'Umar Tusun (1872-1944). ${ }^{27}$

The Egyptian press took great interest in this visit. The Egyptian daily al-Siyāsa, for example, portrayed a picture of the zeal of Egyptians in receiving these special guests from London. Egypt had not welcomed anyone with this much fanfare since the return of the well-known Egyptian politician Sad Zaghlūl (1858-1927) from exile. In al-Bakrīs residence, the journalist met Headley and made the following description: "His Lordship received me with his great polite and nice manners. On his head he wore the Egyptian tarbush (fez) put on his grey hair that reflected the redness [of the tarbush] in a beautiful rosy colour because of his white face and moving blue eyes." ${ }^{28}$

In that interview, Headley revealed the reasons he had converted to Islam. He said that as a child he had doubted many doctrines taught by the church. As he was not an entirely convinced Christian, he considered himself a unitarian, as did many others in Britain and the United States. Thus, even during the years before his official conversion, he considered himself a Muslim. While he was working as an engineer in India in 1883 he read a copy of the Quràn in English translation that had been given to him by a friend and he became impressed by the simplicity of the tenets of Islam. After reading the Qur'an, he discovered that he was a Muslim - and in fact he had not been exposed to any kind of missionary work. He stated that he delayed his public conversion because he did not want to hurt the feelings of the elderly members of his family. ${ }^{29}$

Riḍa did not agree with those Muslims who questioned the Englishman's sincere belief in Islam; he stated that "anybody reading this report with a heart should feel that it was said out of truth and sincerity."30 Furthermore, Riḍā said that it was no surprise that the majority of British people would disbelieve in the traditions of the church, since the British upbringing often takes into account the human fitra (pure disposition), and encourages independent thought. ${ }^{31}$ As a result of Headley's conversion, Rị̂a wished that "if Muslim missionaries went to Britain and the United States and revealed the swindle of politicians and...[Christian] missionaries, who caused enmity and animosity between Islam and Europe, the people of the two countries would actually

\footnotetext{
27 Ibid.

28 As quoted in al-Manār 24, no. 7 (July 1923), 555-559.

29 al-Manār 24, no. 7 (July 1923), 555-559.

30 Ibid.

31 Ibid.
} 
embrace Islam in droves." ${ }^{32}$ In addition, al-Manār translated and quoted some of Headley's works at length, including his A Western Awakening to Islam, in order to counter the arguments of "westernized" Muslims who criticized and distanced themselves from Islam. ${ }^{33}$

Meanwhile, despite Ridâ’s appreciation of the Lahore Ahmadiyya missionary work in Europe, he was critical of their translation of the Qurān into English. The Lahore Ahmadiyya tried to circulate Mawlana Muhammad 'Alī's English translation of the Qurān in Egypt and Syria, but their attempt was resisted by the religious institution of al-Azhar, Rị̣a himself, and his friend Shaykh Muștafā Najā (1852-1932), the mufti of Beirut. In his fatwā, Riḍā saw it as a "deviant" translation that contradicts the principles of Islam. He stated that the translation attempts to destroy Islam from within by disseminating the Ahmadiyya's "false" doctrines on revelation and by abrogating Qur'ānic rulings, such as jihad. ${ }^{34}$ In his view, Rị̣ā emphasized that Muhammad 'Alī intentionally distorted some verses related to the Messiah (al-masịh) in order to argue, based on these verses, that Ghulam Ahmad is the promised Messiah. Ridā urged Muslims not to rely on this translation, or on any other, to understand the Qur'ān, but rather to act according to its rulings in a direct manner. However, Ridā did believe that this translation and other Qurān translations could be used to invite non-Muslims to Islam, particularly those without knowledge of Arabic. ${ }^{35}$

Riḍâ's tone was inconsistent. With regard to the differences between the Lahore and Qadiyani branches in matters of creed ('aqida) and their religious work in Europe, Rịā argued that the Lahore movement agrees with other Muslims in general, except in specific issues related to the death of Jesus and the abrogation of certain verses of the Qurān. Despite their "great" sacrifices

32 As quoted in Ryad, Islamic Reformism and Christianity, 169.

33 al-Manār 26, no. 1 (April 1925), 6o-64 and also see al-Manār 29, no. 5 (Sept. 1928), 344-351. See also Riḍā's recommendation of Headley's works and his cooperation with Indian Muslims during the celebrations of the Prophet's birthday in the early 1930s, al-Manār 32, no. 3 (Feb. 1932), 190-192; al-Manār 32, no. 4 (April 1932), 280-283; al-Manār 34, no. 2 (June 1934), 129-139.

34 al-Manār 25, no. 10 (March 1925), 794-796.

35 al-Manār 29, no. 4 (July 1928), 268-271. See Mohamed Ali Mohamed Abou Sheishaa, "A Study of the Fatwā by Rashid Rị̂ā on the Translation of the Qur'an," Journal of the Society for Qur'ānic Studies 1, no. 1 (Oct. 2001), available online: (http://www.islamicwritings.org/ quran/language/a-study-of-the-fatwa-by-rashid-rida-on-the-translation-of-the-quran/). Cf. Moch Nur Ichwan, "Differing Responses to an Ahmadi Translation and Exegesis: The Holy Qur'ān in Egypt and Indonesia," Archipel 62 (2001): 143-161. 


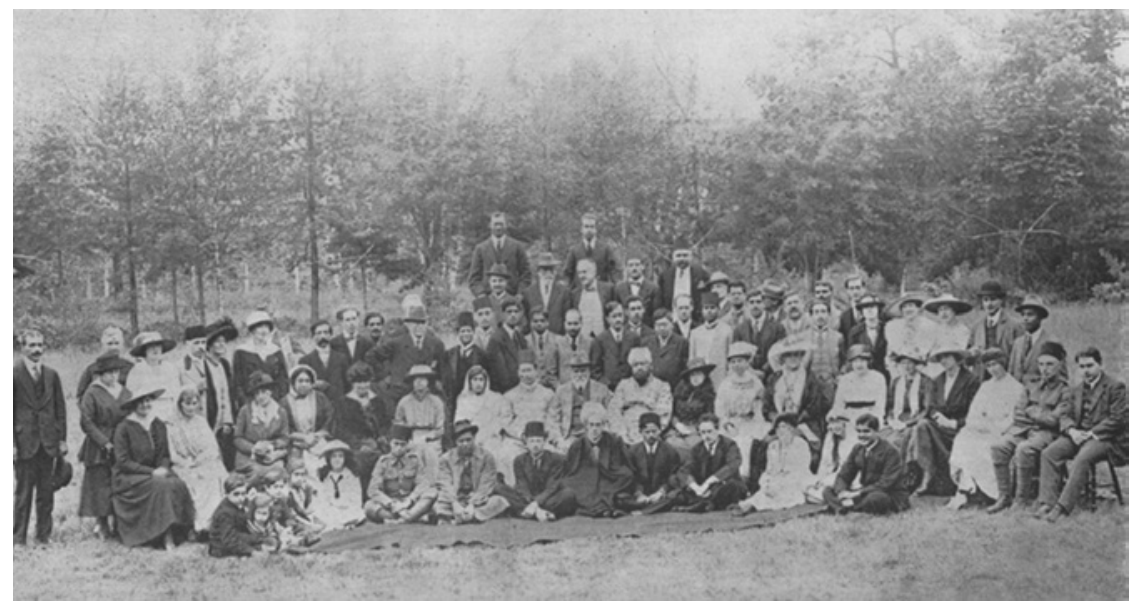

FIGURE 3.2 Id-ul-Fitr day at Woking, 10 July 1918 (The Islamic Review, August 1918) (from the website of the Ahmadiyya Anjuman Ish'at Islam Lahore (U.K.), Wembley, London)

for Islam in India and Europe, Riḍa finally concluded that the Ahmadis of both branches were followers of falsehood $(b \bar{a} t ̦ i l) .{ }^{36}$

Nevertheless, it is strange that Ridā utterly dismissed Kamal-ud-Din from the Ahmadiyya movement. After Khawaja Kamal-ud-Din's death, Riḍa eulogized him for his service for Islam in Europe. A brief biography of Kamal-ud-Din was soon published in al-Manār by Khwaja Abdul Ghani, secretary of the managing committee of the Woking Muslim Mission and Literary Trust in Lahore, as a token of appreciation. Rị̂̄a considered Kamal-ud-Din "the greatest missionary to Islam" in their age. Through his mission, he provided a great service to Islam by converting many high-class British, the most refined of them being Lord Headley. Although Kamal-ud-Din was known as a "moderate" follower of the Ahmadiyya, Rịā was told by many friends who were familiar with his work in Europe, that his activities and writings did not actually reflect any inclinations to the Ahmadiyya convictions as such. ${ }^{37}$

\section{Cutting All Connections with the Mirza: A Populist Salafî Voice}

Riḍā's journal does not reflect any further details about other contemporary European converts. As noted, by the late 1920s, al-Fath magazine had become

36 al-Manār 28, no. 7 (Sept. 1927), 543-550.

37 al-Manār 33, no. 2 (April 1933), 138. 
the mouthpiece of a more populist strand of Salafism. With regard to the Ahmadiyya and European converts in particular, its attitudes, like those of Riḍā, were not always consistent, but its tone was much harsher than al-Manār. Initially, some of the contributors to al-Fath were confused about the Ahmadiyya missionary work and doctrines and their success in Europe. Although Muhibb al-Dīn al-Khațib, the editor of al-Fath, did not express a positive view of the Ahmadiyya and its two branches, and remained very suspicious about their beliefs and missionary work; surprisingly, he allowed other writers to voice positive remarks about their work in Europe. However, throughout late 1930s, as we see, this appreciation was gradually replaced by a harsh campaign against the Ahmadiyya and their missionary work in Europe.

In 1932, the Irish-French convert Khalid Sheldrake (1888-1947), president of the Western Islamic Association in Britian (and also active in the Woking mission in London), ${ }^{38}$ sent a letter to al-Azhar in Cairo asking for a fatwa $\bar{a}$ on the permissibility of building and designing a new mosque in London that would be built by Christian builders in a modern European architectural style; this triggered a heated debate about the Ahmadiyya in al-Fath. The scholars, while aware of the sectarian disputes among Muslims in Britain at that time, replied in the affirmative. However, they advised the questioner to open this mosque to all Muslims, and not favor one sect over another. For the validity of their prayers in the West, the determination of the qibla (prayer direction) should be accurately measured. Al-Fath's editor was impressed by Sheldrake's work and urged Muslims to support him financially. Al-Khațib was probably not aware of Sheldrake's role in the Woking mosque at this time, since he emphatically requested him not to follow the example of the Woking mosque, whose doors were only open to the followers of the Ahmadiyya, at least in the eyes of the editor (this was not entirely correct). ${ }^{39}$

Interestingly, al-Fath was read in London. In response, a certain Ali Muhib, a Muslim living in London and a subscriber of the Ahmadiyya magazine The Islamic Review, immediately noted that this mosque played a great role in spreading Islam in the West and to him, all the preachers in the mosque, including Headley and Sheldrake himself, were Sunnīs. Others who did not follow the Ahmadiyya, such as Sultan Shah Jahan, Begum of Bhopal, ${ }^{40}$ offered

38 About his activities, "Moslem Funeral Service," Irish Times (1 Sept. 1928), 11; “40,00o For London Mosque," Manchester Guardian (27 Feb. 1928).

39 Al-Fath 6, no. 299 (1 July 1932), 15.

40 About him, see Saeedullah, The Life and Works of Muhammad Siddiq Hasan Khan, Nawab of Bhopal: 1248-1307/1832-189o, with a foreword by H.M. 'Abd al-Quddus Qasmi (Lahore: Sh. Muhammad Ashraf, 1973). 
generous donations to the mosque. Ali Muhib reminded al-Fath readers of Kamal-ud-Din's denial of any connection with the Qadiyani branch during his above-mentioned stay in Egypt. Nevertheless, unlike Riḍā, al-Fath did not trust Kamal-ud-Din's words, because he had not completely renounced the figure of Ghulam Ahmad, his claim of prophecy, and the presumed alliance between the Ahmadiyya and the British. ${ }^{41}$

Soon Prince 'Ādil Arslān (1887-1954), the brother of the well-known exiled Druze prince Shakīb Arslān (1869-1946), became involved in the debate by supporting Ali Muhib's arguments. ${ }^{42}$ During the Eid al-Fitr of 1930, 'Ādil Arslān saw that the majority of Muslims in London, even those of different nationalities, preferred to pray in the Woking mosque (despite its remote location from the city center) because of their hatred for the Qadiyani mosque. At the Woking mosque Arslān met with Lord Headley, other British Muslims, the deputy of the Egyptian consul and other Egyptian civil servants in the Egyptian consulate, Shaykh Ḥāfiz Wahba (1889-1967) (envoy extraordinary and minister plenipotentiary of the King of Hijaz in London), in addition to many Egyptians, Yemenis, Somalis, Syrians, Afghanis, and Indians. In a speech after the prayer, Lord Headley urged Muslims to unite and build a bigger mosque in the English capital; one like the Paris Mosque. This mosque should include rooms to house Muslim students and Muslim dignitaries visiting the city. 'Ādil Arslān strongly believed in Lord Headley's "undoubted and great sincerity" for Islam. Therefore, he stated, the Muslim press, including al-Fath, should support Headley's initiative to build this mosque as a meeting place to foster Muslim mutual support in Europe. Arslān was pleased to see Muslims wearing their oriental attire (such as turbans) on that day. Because the British loved such exotic scenes, he believed that the appearance of Muslims like this during the feast days might elevate the position of Muslims in their eyes. Friday prayers were also meant to teach people and answer their queries. "If you visited or resided in these lands," he wrote, "you would be assured that fairness belongs to the nature [of Europeans], particularly when they became persuaded of something."43

$41 \quad$ Al-Fath 7, no. 304 (5 Aug. 1932), 14.

42 'Ādil Arslān, "al-Dacwā ilā l-Islām fỉ l-gharb" [Calling for Islam in the west], al-Fatḥ 7, no. 308 (2 Sept. 1932), 4-5. About him, see, for example, J. Honvault, "Speaking about Oneself when External Life is Ethically Primordial: The Diary of the Sryo-Lebanese Arab Nationalist 'Ādil Arslān (1887-1954)," in Many Ways of Speaking About the Self: Middle Eastern Ego-Documents in Arabic, Persian, and Turkish (14th-2oth Century), ed. Yavuz Köse and Ralf Herausgegeben von Elger (Wiesbaden: Harrassowitz, 2010), 47-58.

Arslān, "al-Da'wa," 4-5. 
'Ādil Arslān compared the missionary zeal of the Ahmadiyya in the West with Protestant and Catholic missions. In the United States, they converted a huge number of people. The only obstruction to spreading Islam among millions of Americans was race: the Ahmadiyya missionaries were not white. Because mainstream Muslims had failed to propagate the "true" essence of Islam, Arslān found no harm in such heterodox Muslim denominations preaching Islam in the West. ${ }^{44}$ Yet al-Fath's editor was still doubtful about the Ahmadiyya missionary work with its two branches in Europe and believed that even the work of Lahore members in London was "futile" as long as they did not recant their conviction in Mirza Ghulam Ahmad. Therefore, he strongly urged Sunnī Muslim dignitaries to support the building of a new mosque in London. ${ }^{45}$

In response to al-Fath's uncompromising stance, Mawlana Abdul-Majid (b. 1896), the acting imam of Woking Mosque (1932-1935), tried to clear the mosque's name of any misunderstanding by stressing that the Woking mosque was a center for the Islamic mission in England and was not limited to a specific sect of Islam. To prove his point, he enclosed a copy of The Islamic Review in which a photo of the Eid prayer was published, showing Muslims from various ethnic groups in the mosque. The prayer was led by the British convert William Burchell Bashyr Pickard. Other leading Sunnī Muslims, such as the mufti of Jerusalem Amīn al-Ḥusaynī and Shaykh Ḥāfiz Wahba, used to lead the prayers in the mosque as well. Abdul-Majid denied any connection with the other Qadiyani group: "I confirm to you that God had bestowed us unprecedented success in these lands only due to our vigorous efforts in propagating pure monotheism; and that the honorable Prophet Muhammad was the seal of prophecy. Our books are enough proofs that we really take distance from any [other] sects." 46

Again al-Khațîb noted that his magazine had avoided becoming involved in polemics with the Ahmadiyya who had been active in Europe for many years, but he was obliged to answer Ali Muhib's remarks. Although the nature of the Woking mosque and its differences with the Qadiyani branch was no secret, he

44 Ibid. Arslān mentioned that Muslims in New York, for instance, used to have their Eid collective prayer in an old theater. As they had neither competent religious guides nor good preachers to help them in their faith, Arslān wrote a letter to the Egyptian ministry of education, requesting that they to dispatch an Egyptian imam to lead the community, but he did not receive an answer.

45 Arslān, "al-Da'wa," 4-5.

46 "Masjid Woking fì London" [Woking mosque in London], al-Fath 7, no. 313 (7 Oct. 1932), $10-11$. 


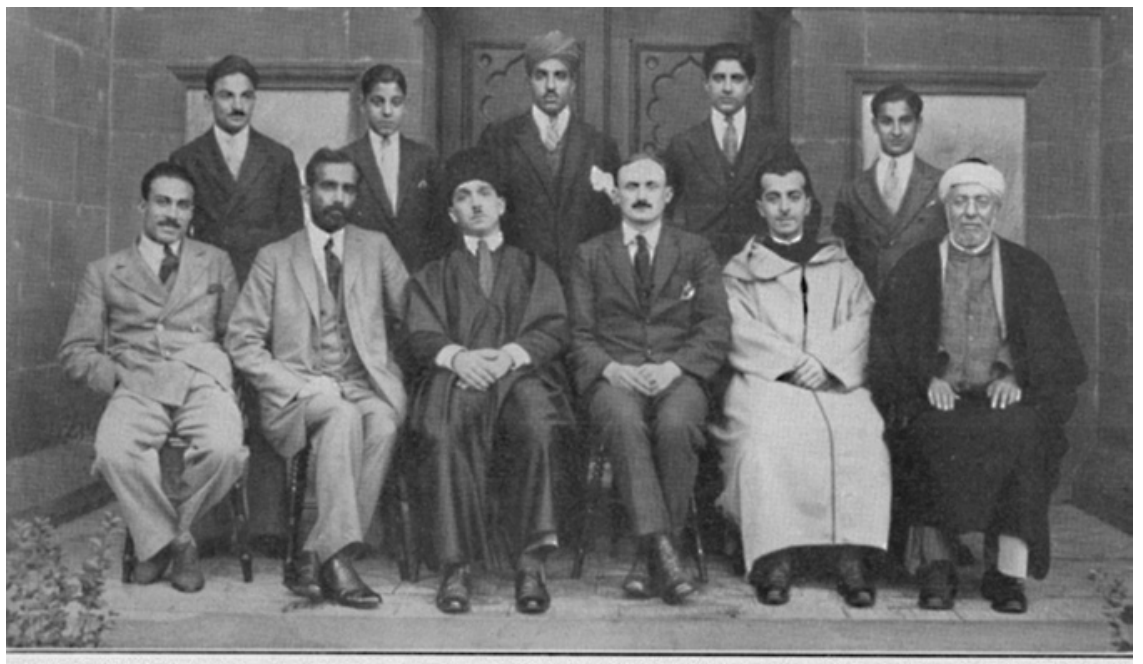

A Fraternal Muslim Group at the Mosque, Woking, with Mr. Omak Hubert C. Rhys Rankin, son of Lt.-Colonel Sis

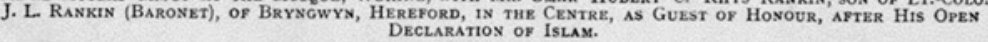

Standing (left to right):-Mr. Qadardad Khan (Secretary). Master Rahim. Mr. Gholam Mohd. Master Faruque. Master Ahmad. Sitting :-Mr. A. Kalique Khan, B.A. (Asst. Imám). Moulvi Abdul Majid, M.A. (Acting Imám). Mr. Abderrahman Hadji.

Mr. Omar Hubert C. Rhys Rankin. Mr. Muhamed Hadji. Prof. Abdul Mohyi (Arab), Mufti, The Mosque, Woking.

FIGURE 3.3 Muslim group at the Woking Mosque, with the convert Omar (later Sir Omar) Hubert Rankin, showing also Abdul Mohiy (The Islamic Review, January 1928) (from the website of the Ahmadiyya Anjuman Ish'at Islam Lahore (U.K.), Wembley, London)

insisted that Ghulam Ahmad was "the most corrupting person that had appeared in Islam in the last [nineteenth] century." ${ }^{77} \mathrm{He}$ urged his followers to sharpen their recantation of this "charlatan and his absurdity." ${ }^{8}$ In al-Khațîb's view, Abdul-Majid's claim that some prominent Muslim figures used to attend their mosque in London is not a valid argument. If al-Khațîb himself one day visited London, he would have no problem praying in the Woking mosque because, from an Islamic point of view, Muslims are allowed to pray anywhere on the earth, as it is all considered pure. ${ }^{49}$

\section{Ahmadiyya in Europe: Useful and Harmful}

At this stage, in Salafĩ circles a dichotomy was made between the positive impact of the Ahmadiyya in Europe and their doctrines, which were considered 
false. As the debate became heated, the Moroccan Salafĩ writer Taqīl-Dīn al-Hilālī (d. 1987), a close associate of Riḍā and Shakīb Arslān, became enthusiastic about the Ahmadiyya work in Europe; he defended European converts' "sincere zeal" for Islam. As a prolific writer in al-Fath, al-Hilāli was at this time in Lucknow where he was working as a lecturer of Arabic literature in Nadwatul-Ulama; and was learning English under the tutelage of a British Christian missionary in India. He also became an avid reader of the Ahmadiyya literature in English, especially the Lahori periodical The Light and the Qadiyani Review of Religion.

Some Muslims in India were doubtful about the sincerity of European converts because of their negligence of their religious duties, an issue that was earlier discussed in al-Manār. Al-Hilālī stated that while hundreds of millions of Muslims might pray and fast, they remained fragile and weak in the world and God's victory on earth will not be given to fasting and praying people only. For example, al-Hilālī deemed the works of the famous translator of the Qurān, Muhammad Marmaduke Pickthall (1875-1936), who was an active convert in the Woking mission, as equal to a "Muslim battalion" in the face of the enemies of Islam. His service for Islam in Europe was far better than the prayers of millions Muslims. He believed that a distinction should be made between the pious work of an individual Muslim and communal work that benefits the Muslim public interest. For al-Hilālī, prayers only benefit the one praying, while such communal acts as translating the Qurān are useful for all Muslims all over the world..$^{50}$

On the basis of his various readings in the Ahmadiyya literature in India, however, al-Hilālī reached a conclusion that the Ahmadiyya mission in Europe was useful and harmful at the same time. Their major and "amazing" religious work in Europe was even more successful than Christian missions in the Muslim world. In his view, because of their work, European converts now had access to some "true" Islamic tenets, even under the disguise of the "invented doctrines" of the Ahmadiyya. The Ahmadiyya, a tiny Muslim group, was capable of achieving what hundreds of millions of Muslims had failed to do for many years. He was sympathetic with their writings and even considered their defense of Islam in the West as a "real jihad" that should please every Muslim. ${ }^{51}$ His main critique of the Lahore Ahmadiyya magazine The Light was that it focused on their "odd" exegesis of the Qurān and their "unfounded" fatwās regarding specific theological issues such as the virgin birth of Jesus. But he distinguished their work from the Qadiyani branch, which remained, in his

5o Muhammad Taqī l-Dīn al-Hilālī, "Fì tarjamat al-Qurān aydan" [Regarding the translation of the Qur’ān, too], al-Fatḥ 6, no. 293 (6 April 1932), 4-7. 
view, more harmful, because of their unyielding conviction that Ghulam Ahmad was the "Promised Messiah." 52

Al-Hilāli ascribed the "usefulness" of the Ahmadiyya's missionary work to their potential "enlightening" of Europeans regarding Islam; they removed the "remnants of myths and fallacies" which "fanatic" Christian clergymen had been disseminating in Europe since the time of the Crusades. On the other hand, the Ahmadiyya work also influenced the image of European soldiers based in the Muslim East by revealing to them the reality of Islam and its Prophet. As a result, they might not take part in what al-Hilāi called the "destruction of Muslims" because of an inherited animosity against Islam. To remain a Christian or to convert to Islam through Ahmadiyya beliefs was for al-Hilālī equal. However, their efforts in removing misconceptions in European minds should be simply recognized as one of their advantages. ${ }^{53}$

In response, Mas'ūd 'Ālim al-Nadwī (1910-1956), co-founder of al-Piyā' magazine and one of al-Hilālì's associates in India, argued that this movement was neither useful to Islam, nor was their "charlatan" Ghulam Ahmad a reformer. ${ }^{54}$ Al-Khațib agreed and added that the Ahmadiyya was a separate "religion" completely opposed to Islam. Their work to convert non-Muslims was therefore useless because they were "corrupting" God's words and the Prophet's sayings with their own interpretations. In this case, one should combat their "damage" to Islam instead of praising them..$^{55}$

At the same time, the debate on the religious works of the Ahmadiyya reached other Muslim regions. For instance, the weekly newspaper Hadramaut launched an anti-Ahmadiyya campaign among the Arabic-speaking community in Indonesia. ${ }^{56}$ They fervently requested that Rashīd Riḍa and Shakīb Arslān stop praising the Ahmadiyya work in Europe; and stand against the Woking mosque and other centers in Europe instead of supporting them. It should be emphasized that Arslān defended the Ahmadiyya, and attended the

$5^{2}$ Taqī l-Dīn al-Hilālī, "al-Qadiyāniyyūn—Bađ̣u ma lahum wa-ma 'alayhim" [The Qadiyanis, the pros and cons], al-Fath 7 , no. 315 (21 Oct. 1932), 9-10.

53 Ibid., 9-10.

$54 \quad$ Al-Fath 7, no. 319 (17 Nov. 1932), 2.

55 Muhibb al-Dīn al-Khațīb, "al-Qadiyāniyya dīn yukhālif dīn al-Islām kamā anna al-Nașraniyya dīn yukhālif dīn al-Yahūd" [Qadiyaniyya: A religion that contradicts Islam just as Christianity contradicts the religion of the Jews], al-Fath 7, no. 320 (24 Nov. 1932), 1-3; Cf. idem, "Islāmunā wa-Islām al-Qadiyāniyyīn" [Our Islam and the Islam of the Qadiyanis], al-Fath 7, no. 322 (8 Dec. 1932), 1-3.

$5^{6}$ In 1932 a series of articles was published in Hadramaut under the title "al-Barāhin al-qat'iyya 'ala butlan al-niḥla al-Qadiyāniyya” [Decisive proofs about the invalidity of the Qadiyani sect] by the Palestinian Azhari shaykh Rabbāḥ Ḥassūna al-Khalīlī. 
inauguration of their mosque in Berlin. The Hadramaut warned that the Ahmadiyya often quoted Jamāl al-Dīn al-Afghānī and Muhammad 'Abduh, as well as al-Manār and Riḍā's Qurānic exegesis only in order to deceive Muslims about the real nature of their faith. ${ }^{57}$ In response, Zeki Kiram Hishmat (1886-1946), a Muslim living in Berlin and a friend of both Arslān and Riḍā,58 tried to refute the claims that Arslān was affiliated with the Ahmadiyya mission in Berlin as it was portrayed in the Indian press. It was true that Arslān used to visit their mosque, but this was only due to Arslān's aspiration to foster Muslim unity in Europe and eliminate any sectarian conflicts. Therefore, in 1932 the Berlin missionary imam of their mosque, S.M. Abdullah, invited Arslān to tea through Kiram, and they accepted. Strangely enough, Kiram implied that neither he nor Arslān had much previous knowledge about the Ahmadiyya's doctrines before this visit. In their publications, which they saw in the mosque, Ghulam Ahmad's adherence to the sharia was confirmed, as were his claims of prophecy and high esteem of the British Crown. ${ }^{59}$ Interestingly, most of the anti-Ahmadiyya campaign brochures were published by the Egyptian Mansur Rifaat in the 1920s at Kiram's publishing house in Berlin, the Morgen- und Abendland Verlag. ${ }^{60}$

\section{Come Back to "Mainstream" Islam}

Such indistinct views continued to circulate in Muslim Salafĩ circles in the early 1930s. Although most of them were aware of the doctrinal differences between the Lahore and Qadiyani branches, they insisted on alluding to both groups as "qadiyani." In reaction to Kiram's above-mentioned article, the

57 Weekblad Hadramaut, Soerabaja (Java), 318 (Feb. 1932).

$5^{8}$ About him, see, Umar Ryad, "From an Officer in the Ottoman Army to a Muslim Publicist and Armament Agent in Berlin: Zekî Hishmat Kirâm (1886-1946)," Bibliotheca Orientalis 63, nos. 3-4 (2006), 235-268.

59 Weekblad Hadramaut, 328 (14 May 1932).

6o For instance, the following by Mansur Rifaat, Die Ahmadia-Sekte: Ein Vorkämpfer für den englischen Imperialismus (Berlin, 1923); Der Verrat der Ahmadis an Heimat und Religion (Berlin, 1923); The Ahmadi Sect: Vanguard of the British Imperialism and the Greatest Danger to Islam, Convincing Evidence of their Duplicity (Berlin, 1923); Ahmadi Betrayal of Country and Religion (Berlin, 1923); Die Ahmadia Agenten: ein Rätsel. Werden sie tatsächlich von den deutschen Behörden unterstützt und beschützet? (Berlin, 1924); Vollständiger Zusammenbruch der Ahmadia-Sekte: Weitere Beweise für Ihre Tätigkeit als englische Agenten (Berlin, 1924); Total Demoralisation of the Ahmadia Sect: Further Evidence in regard to their Activities as British Agents and Menace to Islam (Berlin, 1924). 
Tunisian-Egyptian scholar and later Grand Shaykh of al-Azhar, Muhammad al-Khidir Husayn (1876-1958), branded the Lahore branch as "misguided." He stated that if they had confined the spread of their message to non-Muslims, its "danger" would have been less; their proselytizing work among non-Muslims was tolerated, but their mission among Muslims should be totally rejected. Al-Khiḍr Husayn bitterly asserted that their "greedy" ambitions exceeded the limits of converting non-Muslims and extended to influencing Muslim nations and peoples who were already "guided" by the "light" of the Qur'ān and Sunna. ${ }^{61}$ In order to combat their missionary work among Muslims, ceremonies were organized in Cairo to celebrate former Ahmadiyya members who wanted to denounce their affiliation to the movement publicly. ${ }^{62}$

At this stage, many of these scholars stopped expressing any appreciation of their work, including their missions in Europe. A certain Abū l-Makārim Muhammad 'Abd al-Salām al-Salīm, a lecturer of Arabic in Kurnool, India, requested that Muslim scholars in the East and North Africa, especially in al-Ḥaramayn (the Two Sacred Shrines), Shaykh al-Azhar, Shakīb Arslān, and al-Hilālī, issue a general clear-cut fatwā against the Ahmadiyya. ${ }^{63}$ The dispute then took another radical shift when many contributors to al-Fath penned heated articles against the Ahmadiyya and their doctrines and work. ${ }^{64}$

Shortly thereafter, in response, Shakīb Arslān agreed that specific doctrinal quotations in the Ahmadiyya books could eventually lead to unbelief and apostasy from Islam. Ghulam Ahmad's claimed prophecy would also harm the

61 Muhammad al-Khiḍr Ḥusayn, "Ṭā’ifa al-Qadyāniyya" [A Qadiyani sect], al-Fatḥ 7, no. 317 (3 Nov. 1932), 1-7 and al-Fath 7, no. 319 (17 Nov. 1932), 12-13.

62 In 1932, as founder and president of Jam'iyyat al-Hidāya al-Islāmiyya (Society of Islamic Guidance), al-Khiḍr Husayn welcomed a former head of the Ahmadiyya branch in Cairo and his secretary, who recanted their Ahmadiyya beliefs. This public celebration was attended by the Grand Shaykh of al-Azhar, the founder of the Muslim Brothers Hasan al-Bannā, and other prominent Muslims who congratulated the two men for their "bravery." See, al-Fath 8, no. 375 (14 Dec. 1932), 6-9 and al-Fath 8, no. 376 (21 Dec. 1933), 14-15. The Ahmadiyya center in Cairo was located in al-Khurfush district. It was mainly established to combat Christian missionary work in Cairo, but it was closed down by the police after conflicts with the Muslim inhabitants. Accused of public disorder, three Ahmadiyya members had to pay a fine of one pound each. See al-Fath 8, no. 376 (21 Dec. 1933), 3 and al-Fath 8, no. 377 (28 Dec. 1933), 3. See also, al-Fath, 9, no. 411 (7 Sept. 1934), 20-22; al-Fath 9, no. 415 (4 Oct. 1934), 2-3, 21-22; al-Fath 9, no. 416 (11 Oct. 1934), 18-19; al-Fath 9, no. 417 (18 Oct. 1934), 4.

63 As the highest religious position in Egypt, the shaykh al-Azhar was also required to draw the government's attention to the Ahmadiyya missionary center in Cairo which had to be closed down. Al-Fath 7, no. 324 (22 Dec. 1932), 1-4.

64 Al-Fath 7 , no. 325 (29 Dec. 1932), 5-6. 
Lahore branch if they did not recant it. Arslān, who visited their mosque in Berlin two times, had several discussions with the Ahmadi religious leader in Germany Mawlana Sadr-ud-Din (d. 1981), who repeatedly insisted to him that they merely considered Ghulam Ahmad a reformer. As Arslān had not studied any of their works in any depth, his judgment was mainly based on these meetings in Berlin and various oral reports about their doctrines. However, besides his deep respect for Mawlana Muhammed 'Alī and his writings on Islam, he still admired their zeal and their successful dissemination of Islam, which surpassed all other Muslim organizations in Europe. In Germany, they were successful in converting fifty elite Germans. In his correspondence with the Ahmadiyya Anjuman-i Isha'at-i Islam in Lahore, Arslān frequently advised them to believe in Ahmad as a reformer, and avoid any doctrines outside the boundaries of Islam. He never replied to the Qadiyani branch, who sought his support various times; he avoided any contact with them because of their belief in Ahmad as the Promised Messiah. ${ }^{65}$

Following Arslān, al-Hilālī quickly responded to the fatwā. His previous enthusiasm completely changed after he read some of Ghulam Ahmad's works. He bluntly considered him a "big charlatan...aiming at establishing supremacy, which is a kacba of all evil." ${ }^{\prime 6}$ Claiming to have a firsthand knowledge of their publications and work in India, al-Hilāli became one of the most prominent anti-Ahmadiyya writers in al-Fath. ${ }^{67}$ As for their activities in Europe, he completely changed his mind and wrote sarcastically: "Primary school children of

65 Shakīb Arslān, "al-Jawāb bi Sha’n al-Qadiyāniyya” [A response regarding the Qadiyaniyya], al-Fath 7 , no. 328 (19 Jan. 1933), 6-7.

66 Ibid., 7 .

67 See, for example, his reaction to their views on Islam and prophecy in "Voice of God," The Light (17 July 1933), 3-4: Taqī l-Dīn al-Hilāīi, "Sabb al-Qadiyāniyyīn li-l-Islām I \& II" [The offense of Qadiyanis to Islam I \& II ], al-Fath 8, no. 362 (15 Sept. 1933), 1-5 and al-Fatḥ 8, no. 363 (22 Sept. 1933), 13-16. Soon the anti-Ahmadiyya campaign was fueled in wider circles in Egypt and elsewhere in the Muslim world. See the articles by Shaykh Mușțafā Abū Yūsuf al-Ḥamāmī (d.c. 1949), an Azhari scholar and former imam of the well-known Zaynab Mosque in Cairo, al-Fath 7, no. 329 (26 Jan. 1933), 5-6, 13-14. About his works, see Mușțafā Abū Sayf al-Ḥamāmī, al-Nahḍa al-islāhiyya (Cairo, 1935); Ghawth al-ibād bibayna al-rashād (Cairo, 1950). See also the responses of Țaha Fayyāẹ al-Ānī, an Iraqi lawyer and journalist, al-Fatḥ 7, no. 332 (16 Feb. 1933), 10. Cf. Taqī l-Dīn al-Hilālī, "Bal hiya rābița Qadiyāniyya” [It is a Qadiyani association], al-Fatḥ 7, no. 340 (14 April 1933), 4-5; "al-Barāa min al-Qadiyāniyya" [Clearing one's name from the Qadiyaniyya], al-Fath 8, no. 372 (23 Nov. 1933), 3; al-Fath 8, no. 385 (1 March 1934), 12. See also the reaction by Taqi l-Dīn al-Nabhanī (1909-1977), later founder of Ḥizb al-Taḥrīr, Taqī l-Dīn al-Nabhanī, "al-Qadiyāniyya wa-l-falsafa al-hindiyya" [The Qadiyaniyya and Indian philosophy], 8, no. 372 (23 Nov. 1933), 14-15. 
the Christians in Europe would ridicule and laugh [at their doctrines]."68 Strangely enough, during these heated polemics, al-Hilāli used to quote some Ahmadiyya writings that supported his arguments in questions related to Islamic theology and prophecy in Islam. ${ }^{69}$

Amidst these fierce debates, al-Fath demanded the Ahmadiyya to issue a vehement denial on behalf of the Lahore branch, if they were serious in their claims of being close to Sunnī Islam. Muslims now became convinced that participating in their activities equaled "unbelief." ${ }^{\text {" In }}$ response to this antiAhmadiyya campaign in Egypt, the leaders of the general Ahmadiyya headquarters in Lahore set up a propaganda branch in Cairo in order to clarify their beliefs and the ways that they differed from the Qadiyani movement. But al-Fath remained unshaken in its conclusions: "The consequence of following the Qadiyani Ghulam will be the Hell-fire whether this was based on [the belief] in him as a 'prophet of the devil' or a 'modernizer' of the da'wa of the devil."71

European converts to Islam found themselves in the middle of these sectarian debates in national and transnational contexts. Some of them were active in both the Salafi and Ahmadiyya circles. For a while, their simultaneous activism in various Muslim circles downplayed the tone of bitter hostility on both sides. But eventually Salafi writers demanded that European converts deny any connection with the Ahmadiyya, if they were genuine believers in Islam and Sunnī Muslims. As we shall see, two prominent European figures became the central focus of the Salafi-Ahmadiyya polemic, the above-mentioned British convert Khalid Sheldrake (b. 1888) and the Austrian Baron Omar Rolf von Ehrenfels (1901-1980).

\section{Khalid Sheldrake: A European Sunnī Muslim}

If Headley had occupied a prominent place in al-Manār, Khalid Sheldrake was identified in al-Fath as a zealous new Muslim serving Islam in Europe. In the

68 al-Hilālī, "Sabb II," 13-16.

69 For example, he translated for the readers of al-Fath an article from The Muslim Revival, which was official magazine of the Ahmadiyya Anjuman-i Isha'at-i Islam Lahore (19321936), into Arabic about the "prophecies of world scriptures about the advent of the Prophet Muhammad." Al-Fath 8, no. 373 (30 Nov. 1933), 9-11. Cf. Muslim Revival (June 1933), 22-29.

$70 \quad$ Al-Fath 9, no. 418 (28 Oct. 1934), 8.

71 "Lahūrī Ablah" [A Lahori idiot], al-Fath 9, no. 429 (19 Jan. 1935), 4. They even approached 'Abd al- Hamīd Sa'ìd (d. 1940), the president of the Young Muslim Men's Association, to ask him to organize public events in order to address fellow Muslims about their beliefs in Mirza as a reformer, but not as a prophet. 
early years of his conversion, he became active in the Liverpool Muslim Institute (established in 1889 by the British convert Abdullah Quilliam (18561932)). He defended the Woking mission and regarded the Ahmadis as "part of the rich tapestry of the umma." ${ }^{2}$ By 1914 he claimed to be "Sheikh of the British Muslims," which annoyed the Woking Muslims and British converts, who asked him to leave; he was later readmitted. His congenial ties with the Qadiyanis after their khalifa's visit to London in 1924 irritated other Muslims. In response, Sheldrake clarified his preference for unity above division: "I accepted Islam, and schools of thought mean but little to me."73 In 1926, Sheldrake was again ejected from the Woking mission; but this time he convinced other converts, namely Omar Richardson, Osman Watkins, and Abdullah Day, to leave the Woking mission in order to establish the Western Islamic Association, a separate and non-sectarian Muslim organization. In Sheldrake's family home in South London (sometimes known as Peckham Mosque), they established a prayer room with an information center and distress and welfare fund. In addition, Sheldrake funded other activities, including a short-lived journal, the Minaret, and was able to make a few new converts. ${ }^{74}$

As noted, it was Sheldrake's question regarding the building of a mosque by non-Muslims in London in 1932 that triggered the controversy among Salafi writers about the Ahmadiyya missionary work in Europe. His role and activities in Europe were often portrayed in Salafì circles as those of a European Muslim who had no Ahmadiyya inclination. ${ }^{75}$ However, as late as 1931, Sheldrake wrote to the Lahoris in India that, despite being "unable to associate

72 Gilham, Loyal Enemies, 20o. See, for example, Khalid Sheldrake, "The Religion of Peace," Islamic Review and Muslim India 3 (1915), 25; "The Message to Mankind," Islamic Review 9, no. 1 (Jan. 1921), 21; "Our Duty To-day," Islamic Review 9, no. 2 (Feb. 1921), 71; "Islam and the Unity of Mankind," Islamic Review 9, no. 10 (Oct. 1921), 373; "Practical Experience of Islam," Islamic Review 9, no. 11 (Nov. 1921), 420; “More 'Massacres," Islamic Review 10, nos. 6-7 (June/July 1922), 267; "Muhammad and World Unity," Islamic Review 14, nos. 3-4 (March/ April 1926), 148.

73 As quoted in Gilham, Loyal Enemies, 201.

74 Ibid.

75 Taqī l-Dīn al-Hilālī, "Abdullah Daye: Akh Muslim yasqut min șufūf al-jihād [Abdullah Daye?: A Muslim brother fell down the rows of jihad]", al-Fath 7, no. 325 (29 Dec. 1932), 11. He translated an article by Sheldrake about the death of another British convert to Islam, Abdullah Daye, which the latter published in the Madras magazine Peace-Maker. Sheldrake eulogized him as his "right hand" in their common activities in the Association for British Muslims in England since his conversion in 1929. 
myself any longer with the Woking mission... I remain on the best of terms with the Ahmadiyya Anjyman Ishaat-i-Islam of Lahore." ${ }^{76}$

In November 1932, Sheldrake visited India in order to advance the role of European Muslims in Islamic unity by calling for a European Muslim congress devoted to the study of Muslim problems in Europe, to promote the Islamic $d a^{c} w a$, and to refute any allegations against Islam in Europe. Sheldrake related his conversion story to Arabic readers in order to prove his closeness to mainstream Islam. As he always hoped for Sunni-Shīi unity, Sheldrake observed the Friday prayer in the Great Mosque in Bombay, a Sunnī mosque; and later went to a Shīì mosque for the next prayers. ${ }^{77}$

Sheldrake took pride in European converts to Islam, including Napoleon Bonaparte's alleged conversion (it was said that he kept a copy of the Qur'ān in French with him during his battles and during his exile). Among other names were her Highness Khair-un-Nissa, the Dayang Muda of Sarwak, and her first cousin Conrad (Khalid) Simpson. ${ }^{78}$ Sheldrake received the Dayang Muda of Sarwak into Islam in February 1932. Her conversion created a sensation in Europe, and she later settled in Paris and had a "salon where many grande dames and Muslims meet." ${ }^{\prime 9}$ Interestingly, she embraced Islam while she was in an airplane, crossing the English Channel. As president of the British Muslim Society, Lord Headley regretted her "unfortunate" choice of an airplane for such a serious ceremony, and worried that she had hurt the feelings of many Muslims all over the world. He described her action "as a somewhat freakish departure from the good taste." 80 As for Simpson, he embraced Islam with the idea of helping Sheldrake in his mission, not because of any religious conviction, though he said that he rather liked the concept of brotherhood in Islam. ${ }^{81}$

At this time, Sheldrake became a self-proclaimed suburban king of Tartary and king of Islamistan in western China. He visited the Far East with Conrad Simpson in 1933 and together they received considerable press attention. For example, the English-language daily Singaporean newspaper The Straits Times

76 Gilham, Loyal Enemies, 201.

77 Taqī l-Dīn al-Hilālī, "Khalid Sheldrake fì l-Hind: ḥadīth lahu muhim 'an al-shu'ūn al-Islāmiyya" [Khalid Sheldrake in India: an important talk for him about Islamic issues], al-Fath 7, no. 326 (5 Jan. 1933), 6-7.

78 Al-Fath 7 , no. 327 (12 Jan. 1933). About Bonaparte's conversion, see, for example, Christian Cherfils, Bonaparte et l'Islam d'après les documents français et arabes, with a foreword by Abd El-Hakim (Paris, 1914).

79 "Head of seven million Muslims visits Singapore," Straits Times (26 June 1933).

8o English Moslem Peer Deplores Plane Conversion of Princess," New York Times (2o Feb. 1932), 17 .

81 "Head of seven million...," Straits Times. 
(26 June 1933) was impressed by Sheldrake as the "head of millions of Muslims," whose intention was to connect Muslims in Asia with their "brethren" in Europe. ${ }^{82}$

In India, other Muslim publications doubted Sheldrake's sincerity as a Muslim. The Muslim Review, a monthly review of the shī $\iota$ educational center Madrasatul Waizeen (College of Preachers) in Lucknow, accused Sheldrake of "trading" with religion merely in order to gain wealth through missionary activities in the West, unlike the Woking mosque's people, who were sincere in their dissemination of Islam in Europe. ${ }^{83}$ In a fierce response, the above-mentioned Taqī l-Dīn Hilāili defended Sheldrake's sincerity and efforts to convert many prominent and high-class Europeans and Americans to "true" Islam. Al-Hilālī retaliated, and accused the Ahmadiyya movement of explicitly deceiving Muslims by collecting money from India and elsewhere in the name of Islam in order to propagate their doctrines and to fulfill their own interests. ${ }^{84}$ In al-Hilāli's view, this press campaign against Sheldrake's visit to India was backed by the Ahmadiyya, who did not dare to criticize him in public. In response, al-Hilālī accused Kamal-ud-Din of accumulating a treasure after his arrival in London, and said that he used it only for his own comfort and for his heirs after him. Al-Hilālī, who had earlier highly praised the work of the Ahmadiyya in Europe, now changed his mind completely and said that the Ahmadis had exaggerated their work by enlisting the names of famous European converts, such as Sheldrake, who had in fact converted to Islam much earlier, even before the start of the Ahmadiyya's work in London. As for Lord Headley, al-Hilālī contested his financial integrity as well. In 1928, Headley succeeded in persuading the Nizam of Hyderabad to donate money for the establishment of a mosque in West Kensington, London; the site cost 28 , ooo pounds at the time, but the project was delayed for many years. He also distrusted the choice of the location of the mosque-beside night clubs and cinemas. He blamed Indian Muslims for being "foolish" in donating money to the Woking mosque in order to "propagate the fallacies made by the Prophet of Punjab [Ghulam Ahmad]."85

Sheldrake was accused by the Ahmadis of "flattering" other Muslims by essentially telling them what they wanted to hear. Al-Hilālī saw it as a false accusation because the Ahmadis envied his success among Indian Muslims

\footnotetext{
82 Ibid.

83 Taqī l-Dīn al-Hilālī, "al-Itijār bi-l-dīn" [Trading in religion], al-Fath 8, no. 371 (16 Nov. 1932), 9-12. See also other debates in the Ahmadiyya press during this visit. "Princess Sarawak on Islam," The Light (24 Jan. 1933), 2; "The European Muslims," The Light (8 Feb. 1933), 3; The Light (24 Jan. 1933), 9-10; The Light (24 Feb. 1933), 4.

84 Taqī l-Dīn al-Hilālīi, "al-Itijār," 9-12.

85 Ibid., 10.
} 
after his speech in Calcutta. They intentionally organized the anniversary of Kamal-ud-Din's death on the same day as Sheldrake's lecture, just to compete with him. At this gathering, they distributed free pamphlets with photos of their "prophet" among Sheldrake's audience. Al-Hilālī was surprised that whereas The Light welcomed his trip to India, the Woking mosque in London was "fighting against him by all means." However, in al-Hilāli’s view, the Muslim world highly appreciated Sheldrake's work for the sake of Islam and poor fellow Muslims in Britain. ${ }^{86}$

Al-Hilāli accused the Ahmadis of "paradox and cunning" for "playing" with Sheldrake's name and that of other European converts; but Sheldrake had already uncovered this Ahmadiyya scheme by denying his conversion in their circles. Ahmadi attacks against Sheldrake were deemed as "testimony for him before all Muslims in the world that he seeks God's face only...." ${ }^{17}$ Al-Hilāli argued that the Ahmadi falsely accused him of making the trip to India to collect money in the name of the Muda of Sarawak. ${ }^{88}$ However, it should be noted that Muda of Sarawak received many letters from India regarding the tour of Sheldrake and Simpson in India; and for this reason she distanced herself from their statements on her behalf. 89

At this point, in order to unify all mainstream Muslims, Sheldrake was strongly urged to deny all connections with Ghulam Ahamd and his "absurd" mission as a reformer of Islam. ${ }^{90}$ In the Arab Muslim press in Egypt, Sheldrake distanced himself from the Ahmadi factions and defended his sincerity for Islam in Europe to such an extent that he lost his wealth and family for the sake of his new religion. ${ }^{91} \mathrm{Al}$-Fath boasted about Sheldrake's Muslim missionary activities in the Far East and southeast Asia and declared that he was "the greatest Muslim guide of the age." ${ }^{92}$ At this time, an Egyptian dignitary

\footnotetext{
86 Ibid.

87 Al-Fath 8, no. 371 (16 Nov. 1933), 12.

88 Ibid., 12.

89 The Light (June 1933), 11.

9o An example of that was his support to the Egyptian nationalist Mușțafā Kamīl (1874-1908) during the well-known Dinshwai campaign led by the latter in England in 19o6. Al-Fath 7, no. 327 (12 Jan. 1933), $1-2$.

91 Khalid Sheldrake, "al-Duktūr Khalid Sheldrake yataḥaddath ‘an tārīkh 'alāqatih bi-l-Islām wa yu lin barāatahu min al-Aḥmadiyya wa-l-Qadyāniyya awalan wa-ākhiran” [Dr. Khalid Sheldrake speaks about the history of his relationship to Islam and clears his name from any connection with the Ahmadiyya and Qadiyaniyya], al-Fath 8, no. 383 (15 Feb. 1934), $6-7$.

92 "Al-Duktūr Khalid Sheldrake wa-rihalātuh fì l-sharq" [Dr. Khalid Sheldrake and his trips in the East], al-Fath 8, no. 385 (1 March 1934), 7.
} 
appealed to Shaykh al-Azhar to donate money to the Ahmadiyya movement to support their efforts to spread Islam in England. But the editor of al-Fath was disappointed, and campaigned instead for financial support for Sheldrake's activities; the editor claimed that he served the "genuine" Islam in Europe. ${ }^{93}$ To his Arab readers, Sheldrake did not deny that he maintained good ties with Mawlana Muhammed 'Alī, but this did not mean that he had any direct association with the Ahmadiyya. He said that although the Ahmadis intended to destroy his reputation by linking his name to their mission in Europe, his efforts were still appreciated by many Muslim leaders in Europe, such the Agha Khan, the above-mentioned Hāfiz Wahba, and the Egyptian consul to the United States. He also claimed to be a defender of the Palestinian cause, and sent money for Palestine, and supported the cause of needy Muslim seamen and their families in Britain. ${ }^{94}$ After his trip to the Orient, Sheldrake was keen on presenting himself as a defender of panIslamic endeavors. ${ }^{95}$

\section{Omar Rolf Baron von Ehrenfels: A Controversial Convert}

While Sheldrake was closely engaged with Salafì groups in Egypt, the abovementioned Baron von Ehrenfels became a controversial convert in these circles because of his evident connection with the Ahmadiyya in Berlin. ${ }^{96}$ Initially, von Ehrenfels was praised by the Ahmadiyya for his founding role in the establishment of the Islamische Kulturbund (Association of Muslim Culture) in

93

94 Khalid Sheldrake, "Li-mādha yaḥmilu 'alayya al-Aḥmadiyyūn?" [Why are the Ahmadis against me?], al-Fath 9, no. 421 (15 Nov. 1934), 22-23.

95 Khalid Sheldrake, "Mustaqbal al-Islām" [The future of Islam], al-Fath 9, no. 434 (21 Feb. 1935), 12-13. Khalid Sheldrake, "al-Yapān wa-l-Islām al-ḥaqq" [Japan and genuine Islam], al-Fath 9, no. 439 (5 April 1935), 18-19.

96 See some of Baron Omar Rolf von Ehrenfels' works: "Islam and the Present Generation in Europe," Islamic Review 20, no. 11 (Nov. 1932), 383; "Muslim Women in Present-Day Europe," Islamic Culture 24, no. 10 (July 1936), 471; "The Pre-Aryan Cultures of India and the Ethnological Background of Islam," Islamic Culture 13, no. 2 (April 1939), 176; "Ethnology and Islamic Sciences," Islamic Culture 14, no. 4 (Oct. 1940), 434; Mother-Right in India (Hyderabad: Government Central Press, 1941); "A Scheme for Equitable Distribution of Zakat," Islamic Review 34 (1946), 407; “The 'How?' and 'Why?' of Conversion to Islam," Islamic Review 49, no. 6 (June 1961), 23; "Islam und Wissenschaft," Kairos: Zeitschrift für Religionswissenschaft und Theologie 5 (1963), 114; Das Kulturproblem der Entwicklungshilfe im Südasiatischen Raum (Heidelberg: Universität Heidelberg. Südasien-Institut, 1966). 
Vienna. ${ }^{97}$ However, the Ahmadis were criticized by Khalid Simpson for having given little credit to the Egyptian medical doctor Zākì 'Alī, an associate of Arslān, and for his co-founding role with von Ehrenfels in the Islamische Kulturbund in Austria. Moreover, it was Zākī 'Alī who also tried in collaboration with Sheldrake to organize the Muslims of central Europe. ${ }^{98}$ In response, the Ahmadis apologized for this unintentional mistake and stressed that other Muslims working in Europe, including Sheldrake, should be given due credit. They warned other European Muslims against "imbibing the virus which has sapped all validity out of Eastern Muslims. Mr. Simpson's letter plainly shows that some so-called 'friends' of his have been trying to inject the same poison into him." ${ }^{99}$ Therefore, sectarianism should be denounced by European Muslims in order to proceed with the "Islamization" of Europe. ${ }^{100}$

In 1932-1933, von Ehrenfels traveled to India accompanied by Muhammad S. Abdullah, the imam of the Ahmadiyya Berlin mosque. As in the press coverage about Headley's visit to Cairo almost ten years before, von Ehrenfels' arrival in Lahore was described by the Ahmadi magazine The Light: "as the Frontier Mail slided in, the platform resounded with shouts of Allah-o-Akbar. On alighting from the train, the Baron and the Imam were profusely garlanded and it was stilt great difficulty that a way could be forced out of the huge crowd to the car, bedecked with flowers."101 Taqī l-Dīn al-Hilālī translated The Light's report about von Ehrenfels' visit, the welcoming of the Ahmadiyya to his project to translate the Quraan into German, and the plans to start a Muslim mission and build a mosque in Vienna. Al-Hilāī saw the Baron's choice of India to increase his knowledge of the Islamic sciences as an unfortunate one. He chose India because Qadiyani (he did not use the Lahori) Muslims were not welcomed anymore in Egypt, the Hijaz, Yemen or Syria. The Ahmadis allegedly kept von Ehrenfels away from the centers of "Muhammadan Islam" for fear that their "fallacies" would be unearthed. ${ }^{102}$

97 "Iḥtifāl al-Muslimīn fī l-Nimsā bi-ta’sīs rābițat al-thaqāfa al-Islāmiyya" [Celebration of Muslims in Austria to the inauguration of the Association of Muslim Culture], al-Fath 7, no. 324 (22 Dec. 1932), 15. It enthusiastically announced its inaugural festivity and postal address in Austria without giving any reference to its Ahmadiyya character.

98 "The European Muslims," The Light (8 Feb. 1933), 3.

99 Ibid., 4.

100 Ibid.

101 "The Anjuman's Anniversary," The Light (Jan. 1933), 1.

102 Taqī l-Dīn al-Hilālī, "al-Baron Omar Rolf al-Nimsāwī aslama islāman qadiyāniyyan" [The Austrian Baron Omar holds a Qadiyani Islam], al-Fath 7, no. 337 (24 March 1933), 14. To combat the Ahmadiyya Light magazine, he suggested that the English supplement of 
Baron von Ehrenfels publicly announced that he never denied Zākì 'Alī's support as a secretary of Kulturbund in Vienna; and said that he had he always had good "brotherly" relations with him. ${ }^{103}$ Meanwhile, on behalf of the Kulturbund, a certain Muhammad Saljaq al-Busnawī, a member of the Kulturbund's board, strongly rejected the "rumors" ascribed to the Baron that he had converted to Islam according to the Ahmadiyya doctrines; and that their society was connected in any way to the Ahmadiyya movement in Europe. Zākī 'Alī's main objective was to establish an Islamic center in the heart of Europe. His choice of the Baron as its president was because of the latter's sincerity and fame as a European writer. It was a condition of the board that the Baron should not attach himself to any Muslim organization that was at odds with the mainstream consensus in the Muslim world. The Kulturbund had several connections with Muslim organizations, including the Ahmadis. This was, therefore, the reason he was invited to deliver lectures in India in many Muslim circles, including the Ahmadiyya in Lahore. The Kulturbund's board warned von Ehrenfels against expressing any direct affiliation with the Ahmadiyya, or, they said they would be compelled to replace him in that position. They also sent a declaration to the Indian press regarding this issue. ${ }^{104}$ Al-Khațīb was relieved by this news and appreciated the Kulturbund's publicity in India. "If my father were connected to the Qadiyanis," he wrote, "I would launch a 'war' against him and would warn all Muslims against him."105

\section{Sense of Competition and Climax}

In this context, and because they perceived a sense of competition with the Ahmadiyya missionary work in Europe, al-Fath became keen on countering their missions by reporting the "success" of non-Ahmadiyya Muslim missions in Europe. ${ }^{106}$ They strongly urged Muslims to form a front of European and American converts who could stand up to the spread of Catholic and Protestant allegations against Islam. The historical changes in Europe of that time

\footnotetext{
al-Azhar mouthpiece, Nūr al-Islām, should include a chapter entitled: "The Light of Islam" in which anti-Islamic ideas could be refuted.

103 The Light (24 Feb. 1933), 4.

104 "Bar’a min al-Qadiyāniyya" [Innocent of being a Qadiyani], al-Fatḥ 7, no. 340 (24 April 1933), 14.

105 Ibid.

106 Ḥasan Anwar, "al-Daćwa ilā l-islām fī Ūrubā" [Islamic mission in Europe], al-Fath 8, no. 381 (1 Feb. 1934), 6-7.
} 
indicated that it was a suitable time to launch such solid Islamic missions in Europe. After World War I, the European and American public had changed; and it was high time for Muslim missionaries to clarify the "values of Islam" in Europe. In the past, western political parties and leaders had nourished the western Christian public opinion against Islam in order to get rid of Muslims on the European continent. This spirit thoroughly dominated in Europe before the war, and negatively effected Muslim minorities in these states, especially in Hungary and Poland. Therefore, al-Khațîb saw it as a pressing issue for Muslims to strengthen their presence in Europe by establishing religious, economic, and social relations with Europeans. He especially lamented the "weakness" and "ignorance" of Muslims in eastern Europe, and hoped that the European Muslim Congress (1935) in Geneva would sustain them in their religious affairs. ${ }^{107}$

Previous conversions in the Woking mosque were again brought into question. These accounts were confused. A certain Ahmad al-Sharîf, an Egyptian living in Berlin, cast doubt on the authenticity of Lord Headley's conversion to the "true" Islam. ${ }^{108}$ Despite this clear anti-Ahmadiyya line of thought, the conversions of new European Muslims were confused and inconsistently recalled in these Salafì circles. For example, Lord Headley's role in the conversion of other elite British people to Islam was eulogized. An Arabic summary of the introduction of Lady Evelyn Cobbold's book, Pilgrimage to Mecca, ${ }^{109}$ which was about her conversion, was discussed in al-Fath at length without referring to her active role in the Woking mosque in London. ${ }^{110}$

The disputes about the Ahmadiyya's position in Europe resonated among Egyptian readers. Some Egyptians were already in contact with the Woking mosque. A certain Mahmūd Ḥamdī 'Alī, president of the association of al-Muslim al-Ämil (the Active Muslim, which was affiliated with the Muslim Brothers) in Cairo, was a reader of Ahmadiyya (such as The Islamic Review) and Salafi journals. Being confused about their religious work in Europe, he contacted the Woking mosque in London (August 1934) with an inquiry about the prevailing "rumor" in

\footnotetext{
107 Al-Fath 8, no. 399 (4June 1934), 1-3.

108 Aḥmad al-Sharīf, "al-Lāhūriyyūn wa-Britānia" [The Lahoris in Britain], al-Fath 9, no. 423 (29 Nov. 1934), 20-22. See also al-Fath 9, no. 426 (20 Dec. 1934), 11.

109 Al-Fath 9, no. 429 (18 Jan. 1935), 11. See also, William Facey, "Mayfair to Makkah," Saudi Aramco World 59, no. 5 (2008): 18-23; available online: http://www.saudiaramcoworld .com/issue/200805/mayfair.to.makkah.htm (accessed 20 March 2014).

110 Cobbold's name was also enlisted in the Ahmadiyya volume of conversion stories of Europeans. Khwaja Nazir Ahmad Cobbold, Charms of Islam: A Collection of Writings of Some of the Eminent Scholars (Woking: Woking Muslim Mission \& Literary Trust, 1935), $45^{-47 .}$
} 
Egypt that concerned their propagation of the prophecy of Ghulam Ahmad in Europe."11 The Islamic Review published 'Ali's letter after a few months and stressed that their mosque was neither a Qadiyani nor an Ahmadi movement. They believed in the Prophet Muhammad as the seal of prophecy, and belonged to the Hanafi school of thought. Any claimant of prophecy after him was considered beyond the pale of Islam. ${ }^{112}$ In al-Fath, 'Alī noted that his message was effective because the magazine changed its Arabic caption from "naḥmaduh wa nuṣalli 'ala rasūlih al-karīm" (we thank Him [God] and our prayers are upon his generous prophet) to "naḥmaduh wa nuṣallì wa nuṣallim 'ala rasülih Muhammad khațam al-nabiyyin" (we thank Him and our prayers and greetings are upon his messenger Muhammad, the seal of prophecy). ${ }^{113} \mathrm{Al}$-Fath tried to convince its reader that the Lahore branch was rather a "chameleon," that changed its "colors."14

Those in the Salafĩ circles were not clear about the nature of the Ahmadiyya work in Europe. The same Mahmmūd Ḥamdī 'Alī published an Arabic translation of the 1934 Eid al-Adha sermon delivered in the Woking mosque by the above-mentioned envoy extraordinary of the King of Hijaz in London Shaykh Haafiz Wahba. This article was placed in al-Fath a few pages after a thorny antiAhmadiyya article written as part of a series by the former president and secretary of the Ahmadiyya branch in Cairo. ${ }^{115}$ The editor of al-Fath, a great sympathizer of the King of Hijaz, probably forgot that Haafiz Wahba was a regular visitor to the Woking mosque. It should be noted that Wahba was close to the imam of the mosque and delivered the sermons there several times. ${ }^{116}$

Nevertheless, in the mid 1930s these inconsistent attitudes coincided with the peak of the anti-Ahmadiyya campaign in the Muslim press worldwide. Still, it was sometimes presumed that the Woking mosque was not directly affiliated with the Ahmadiyya because of their defense of Sunnī Islam and the reception of Muslim dignitaries visiting Britain. On 30 June 1935, Prince Sa ūd, eldest brother of King 'Abd al-'Azīz Āl Sa'ūd, was cordially received at the Woking mosque during his visit to London. ${ }^{117}$

\footnotetext{
111 See Islamic Review (March 1935), 108.

112 Ibid., 81.

113 Islamic Review (Sept. 1934), 1.

114 al-Fath 9, no. 445 (16 May 1935), 17-18.

115 See al-Fath 10, no. $45^{6}$ (2 Aug. 1935), 13-15; cf. 18-19.

116 See, for example, Islamic Review (July 1934), 221-223. See Wahba's photo with his signature in Islamic Review (March-April 1931).

117 Islamic Review (Aug. 1935).
} 
Meanwhile, al-Fath announced, as surprising news, that the Woking mosque had been finally and conclusively "unmasked" as an Ahmadi religious institution after years of vacillating. Although many Muslims, both in the Muslim world and in Europe, were still confused about its nature, the affiliation of the Woking mosque with the Ahmadiyya became evident after the Ahmadiyya representative in Cairo distributed Mawlana Muhammad 'Alī's book, al-Bayān fìl-rujü' iläl-Qurāan, in which the author openly stated that the Woking mosque in London and the Muslim Mission in Berlin were associated to the Lahore Ahmadiyya. ${ }^{118}$

By this time, Shaykh Muḥammad 'Abd al-Salām Salīm al-Hazarwī (Hazarvi) (1898-1947), ${ }^{119}$ a well-known teacher of Islamic sciences in Mysore (India), was keen on informing his Arab "brethren" through al-Fath about the real nature of the Woking mosque and their "hypocrisy." As one of the fiercest opponents of the Ahmadiyya in the region, al-Hazarwi urged people to boycott the Ahmadiyya altogether. In May 1935, Abdul-Majid, the imam of Woking, and Khwaja Abdul-Ghani, secretary of the mosque, visited al-Hazarwī in order to convince him that their mosques and activities in Europe were neither associated to the Qadiyanis, nor to the Lahore line of belief, rather, they stated, they were followers of Ahl al-Sunna wa-l-Jama'a. During this meeting, al-Hazarwi requested that they sign a paper on which they clearly state that Ghulam Ahmad was an unbeliever ( $k \bar{a}$ fir ) because of his claim of prophecy, but they refused. This was, for al-Hazarwī and al-Fath, definitive proof of their separation from Islam. ${ }^{120}$

The above-mentioned Egyptian Mạ̣mūd Hamdī 'Alī gently blamed al-Khațib for persisting in this stance regarding the Muslims of the Woking mosque, who did not explicitly consider Mirza Ghulam Ahmad as a prophet. But al-Khațîb remained adamant in his position. For him, the Ahmadiyya Lahore missionaries, including Mawlana Muhammad 'Alī and Kamal-ud-Din, were clandestinely concealing their real nature behind their claim that the Mirza was a reformer, in order to achieve their goals, which ultimately served British colonial interests. ${ }^{121}$ In the view of al-Fath, another proof of their hatred of Islam was the joy expressed by a Qadiyani paper in India at the death of

\footnotetext{
118 al-Fath, 10, no. 475 (12 Dec. 1935), 6.

119 About him, see online at: http://www.almoajam.org/poet_details.php?id=3920 (accessed 20 March 2014).

120 al-Fath 10, no. 454 (18 July 1935), 8-10.

121 al-Fath 10, no. 456 (2 Aug. 1935), 8-10; see also, al-Fath 10, no. 461 (5 Sept. 1935), 14-15; al-Fath 10, no. 464 (26 Sept. 1935), $16-17$.
} 
Rashīd Riḍā; it stated that his demise was the "perishing of the first and the strongest adversary of the Promised Messiah...in the Muslim world."122

European converts started to demand that the Woking leadership disassociate themselves from the Ahmadiyya. Led by Sheldrake, a group of British converts, including Sir Omar Hubert C. Rhys Stewart-Rankin (1899-1988) and Sir Charles Edward Abdullah Watkin Hamilton (1876-1939), disclaimed any relationship with Lord Headley, and regretted their earlier friendship with the Ahmadiyya altogether. To Sheldrake, the Ahmadis were "tricky people" who caused him "pain."123 At this point, some British converts severed their ties to the Woking mosque. After Headley's death in 1935, Omar Stewart-Rankin succeeded him as president of the British Muslim Society. A month later, he resigned after a meeting with the Woking members during which he put forward a resolution that the mosque should not have any connection with the Ahmadis in India. When his resolution was defeated, Stewart-Rankin and other members walked away. He decided therefore to form a new "orthodox and non-sectarian" Muslim society. ${ }^{124}$ Stewart-Rankin's move was seen by some other converts as a "non-sensical split...through his impulsiveness." ${ }^{25}$ Mubarak Fuelling, a Qadiyani British convert, even criticized this split by arguing that most British Muslims were "led like sheep in all matters that affected Islam by any man from the East who had a beard or spoke Arabic."126

A few days later, al-Khatịb received the news of Stewart-Rankin's split from the Ahmadiyya in London with great joy. For him, it was now the right time to "purify" the Islamic da'wa in Britain from the "filth" of the Ahmadiyya. He boasted that it was his magazine that raised its "gentle voice" against their work in Britain from the start. But his "good intentions" regarding the Woking mosque and The Islamic Review in the beginning were spoiled by mosque's refusal to clearly distance itself from Ghulam Ahmad. He saw Stewart-Rankin's resignation as a result of anti-Ahmadiyya voices in the Muslim world. ${ }^{127}$

Similarly, at the invitation of the Islamische Gemeinde in Berlin, a group of more than fifty Muslims living in Berlin gathered and issued a declaration to the Muslim world to condemn and boycott the Ahmadiyya activities in Europe. They denounced their work as "charlatanry" in the name of Islam. The list included Arab, Indian, and European names, such as the converts Walter

\footnotetext{
122 al-Fath 10, no. 470 (7 Nov. 1935), 13.

123 Sheldrake, "Li-mādha," 14-15. See al-Fath 9, no. 417 (18 Oct. 1934), 4.

124 "British Muslims' Leader Resigns," Times (12 Dec. 1935).

125 See Gilham, Loyal Enemies, 204.

126 Ibid.

127 al-Fatḥ 10, no. 476 (19 Dec. 1935), 6-7.
} 


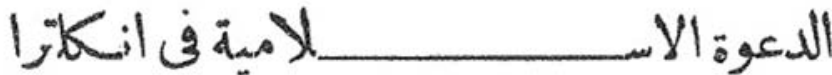

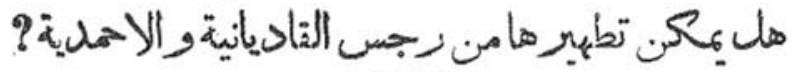 \\ eององ}

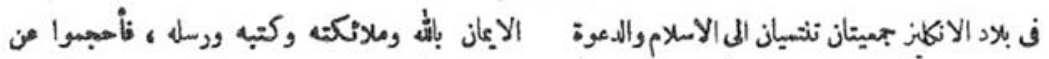

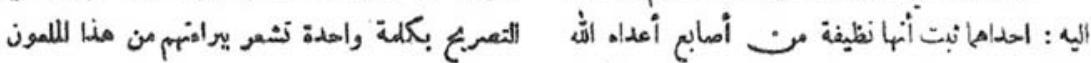

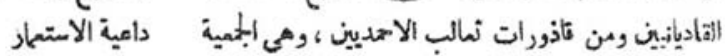

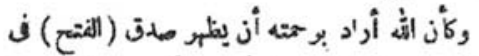

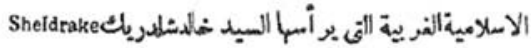

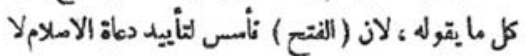

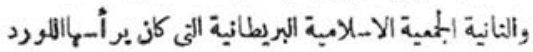

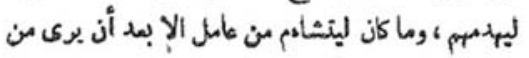

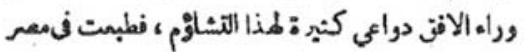

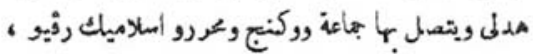

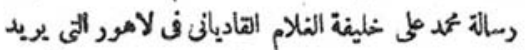

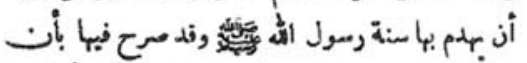

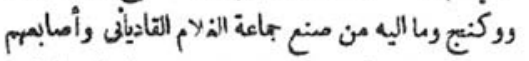

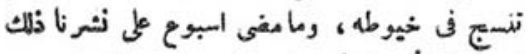

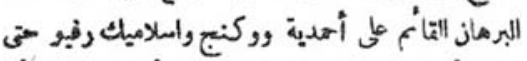

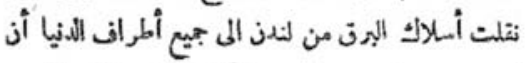

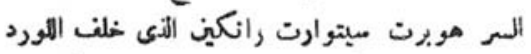

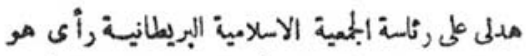
وبعض اخوانه المخلمبن أز الصبغة القاديانية بلمعيته

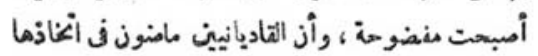

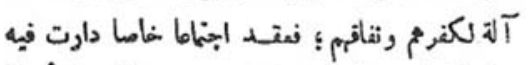

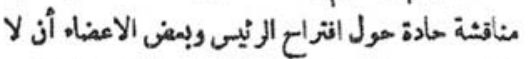

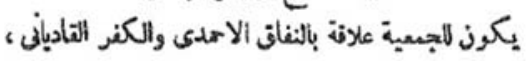

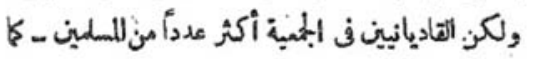

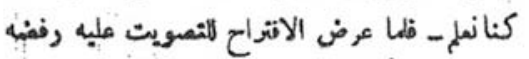

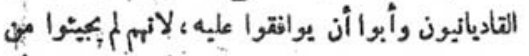

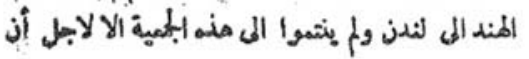

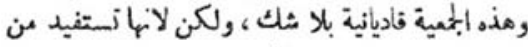

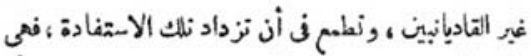

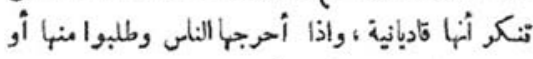

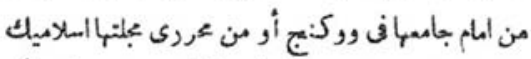
رثيو اعلان البراهة من الدجال الكذاب الغلام القاديانى

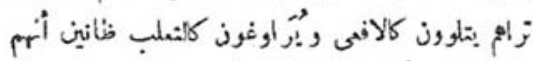
يستطيمون أن بضخكون بذلك ملى الناس بئلا الناس

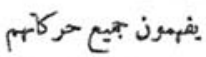

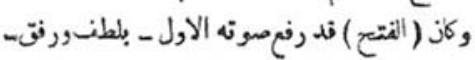

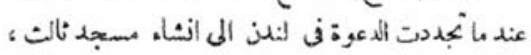

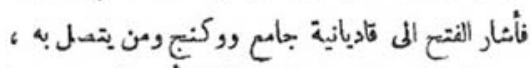
زوق ذلك عليجم كالماعقة ، وماولوا أن بخاد عوا قراهنا

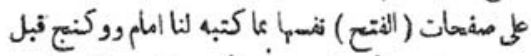

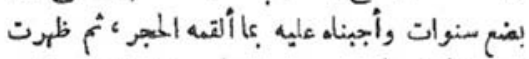

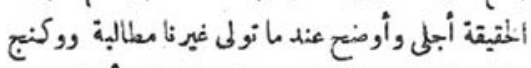

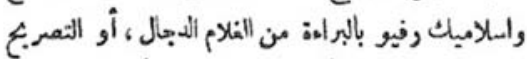

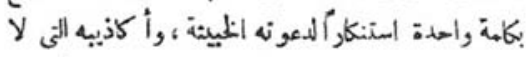

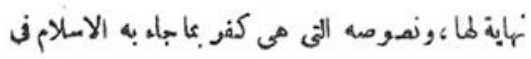




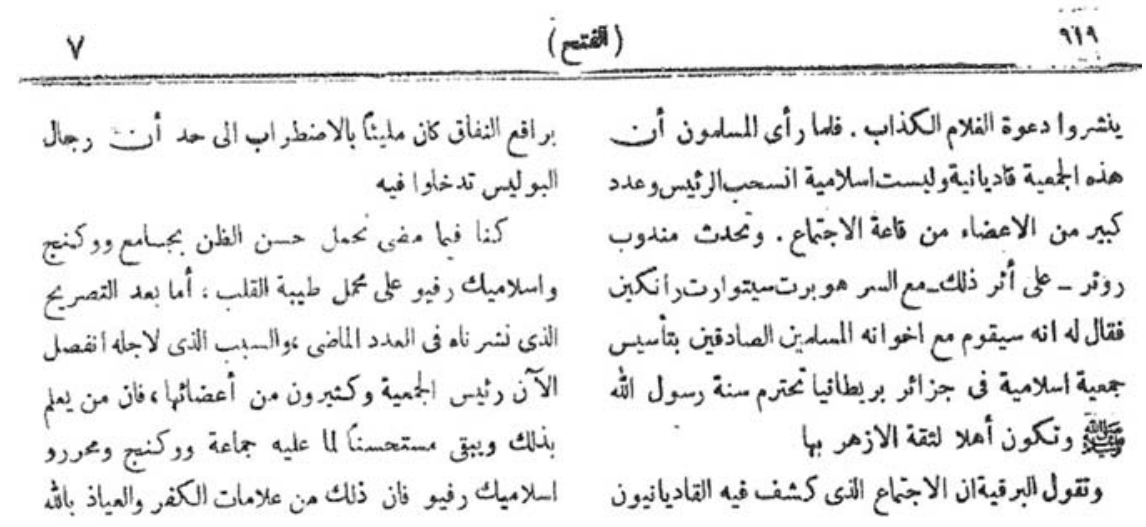

FIGURE $3.4 \quad$ (continued)

Mohammed Hasan Hoffmann, Chalid-Albert Seiler-Chan, Faruq Fischer, and S. Umar W.A. Schubert, ${ }^{128}$ who later supported the establishment of another Muslim congregation in Berlin.

\section{Conclusion}

As we have seen, the individuals analyzed in this chapter followed specific paths that elucidate, in different ways, the many worlds in which they lived. In particular, the history of European converts to Islam highlights aspects of the shifting patterns of interaction not only between Muslims and European society, but also with the global Muslim community in the interwar period. It is clear that they, as European actors, crossed boundaries in the transcultural history of the period; this was a result of their active role as new Muslims connecting the East and West. Their role was also a function of the intra-Muslim religious debates between the Salafiyya and Ahmadiyya as conflicting branches of Islam of that time.

As a matter of fact, the multifold and deeply-rooted conflicts between the Salafiyya and Ahmadiyya were uncompromising. However, we have observed that the presence of European converts as new and engaging figures unconsciously created a certain commonality between these disagreeing Muslim branches through their entwining role in Europe. They all had one goal in common, namely the relevance of Islam on European soil. The chapter has also tried to demonstrate the interconnected history of the Salafiyya, Ahmadiyya,

128 al-Fath 10, no. 478 (2 Jan. 1936), 17. My gratitude to Gerdien Jonker for her help in identifying these figures. 
and European converts in a common past that was not only characterized by enduring conflict, but also by the exchange of ideas. In other words, these conflicts were not always primarily translated into complete boycott, but knew many blurry zones. This can be seen quite clearly in the unprecedented Egyptian welcome of Lord Headley despite his Ahmadiyya affiliation. As for the case of the Salafi-leaning journal al-Fath, despite its editor's vehement dislike of the Ahmadiyya, he allowed many writers to express positive remarks about the Ahmadiyya's role in Europe.

Salafî responses to the Ahmadiyya in Europe were ambivalent. Initially, some Salafi writers recognized the significance of the symbolic and organizational centrality of the Woking mosque in the interwar period and its importance for the presence of Islam in Europe in general. Nevertheless, Addison's remarks in 1929 on the reluctance of the Lahore group to admit any connection with the Ahmadiyya movement, especially their eagerness to modify their message according to the fashion of the hour, correctly corresponds with the hesitant appreciation of the reformist figures discussed in the chapter. It may be no surprise therefore that Riḍa did not consider Khwaja Kamal-ud-Din after the latter's death as a true follower of the Ahmadiyya.

The change of the Salafiyya movement to a more "populist" turn radically affected the image of the Ahmadiyya in the Muslim world. Al-Fath, which was, initially, somewhat positive about the Ahmadiyya's missionary work in Europe, boldly demanded that the Lahore group disavow their connection with Mirza Ghulam Ahmad altogether. In 1940, Hasan al-Banna, the founder of the Muslim Brothers, continued the anti-Ahmadiyya campaign when he became the editor of al-Manār at the request of Ridâ̄'s family. ${ }^{129}$

Among European converts, Lord Headley and Khalid Sheldrake occupied prominent places in Salafĩ circles. Headley remained closely connected to the Woking mosque until his death in 1935, while Sheldrake maintained close contacts with Salafĩ circles in the East. Despite his several writings in Ahmadi publications, he ultimately created a swift anti-Ahmadiyya backlash in the Muslim Salafì press. In the late 1930s, Sheldrake disappeared from the scene and became a business representative in Turkey and a part-time employee of the British Council in Ankara. He died in London in 1947, three years after his return to Britain. Despite his role in the formative making of British Islam, his death was ignored in the British and mainstream Muslim press. ${ }^{130}$ David/Dawud Cowan (1915-2003), a British convert and assistant imam in the Woking mosque, recalled to Gilham many decades later that "Sheldrake was considered a bit of

129 al-Manār 35, no. 7 (April 1940), 443.

130 Gilham, Loyal Enemies, 237. 
a charlatan...Various people said Sheldrake talked about Islam for the profit of British secret service."131 Although one must take such later testimonies with a grain of salt, they reflect at least the images made among these converts amid such disputes.

Interwar European converts still occupy a special place in the writings of some prominent contemporary Muslim scholars in the generation after World War II. For example, the well-known Grand Shaykh of al-Azhar (1910-1978), 'Abd al-Halīm Mạmmūd, was an al-Azhar student completing post-graduate degrees in Europe in the 1930s. In Paris, he met with Khalid Sheldrake in the literary salon of Dayang Muda of Sarwak, where he was impressed by this intellectual sphere that gathered European converts to Islam in the French capital. ${ }^{132}$ This experience led this traditional Azhari scholar to write his famous book on the relationship between Europe and Islam. Mahmūd cited Lord Headley, along with the French convert to Islam Étienne Dinet (18611929), as an exemplary European Muslim who rendered a great service to Islam in Europe; Mahmūd avoided any reference to Headley's Ahmadiyya background in the interwar period. ${ }^{133}$

\section{Bibliography}

Abou Sheishaa, Mohamed Ali Mohamed. "A Study of the Fatwā by Rashid Ridā on the Translation of the Qur'an." Journal of the Society for Qur'änic Studies 1, no. 1 (Oct. 2001). Online: http://www.Qur'ān.org.uk/out.php?LinkID=61 (accessed 24 March 2014).

Addison, James Thayer. "The Ahmadiya Movement and Its Western Propaganda." Harvard Theological Review 22, no. 1 (January 1929).

Ahmad, Mirza Ghulam. al-Hudāwa-l-tabșira limanyarā.Tilford, Surrey, UK:al-Shirkatul al-Islāmiyya Limited, 2011 (repr. 1902). Online: http://www.islamahmadiyya. net/books2.asp?book_key=67\&magazine $=0$ (accessed 20 March 2014).

- Ijäz al-masih. Tilford, Surrey, uk: al-Shirkat al-Islamiyya Limited, 2011 (repr. 1901).http://www.islamahmadiyya.net/pdf/ijaz_maseeh_full.pdf.

131 Ibid., 289. Cowan was later employed in the Middle East section of the ministry of information, Gilham, Loyal Enemies, 216.

132 'Abd al-Ḥalīm Mạ̣mūd, al-Hamdu li-Llāh hadhihi hayātī (Cairo: Dār al-Macārif, 1985), 121-122; for more about him, see Hatsuki Aishima, "'Abd Al-Halim Mahmud (1910-78) and his Audiences: Mass Media and the Transformation of Islamic Learning in Contemporary Egypt" (PhD diss., University of Oxford, 2011).

133 'Abd al-Ḥalīm Maḥmūd, Uruba wa-l-Islām (Cairo: Dār al-Ma'ārif, 1991), 67-72. 
Aishima, Hatsuki. "Abd al-Halim Mahmud (1910-78) and his Audiences: Mass Media and the Transformation of Islamic Learning in Contemporary Egypt." PhD dissertation, University of Oxford, 2011.

al-Ānī, Ṭāha Fayyāḍ. al-Fatḥ 7, no. 332 (16 Feb. 1933).

Ansari, K. Humayun. "The Woking Mosque: A Case Study of Muslim Engagement with British Society since 1889." Immigrants \& Minorities 21, no. 3 (2002).

Anwar, Ḥasan. "al-Da'wa ilā l-islām fī Ūrubā" [Islamic mission in Europe]. al-Fath 8, no. 381 (1 Feb. 1934), $6-7$.

Arslān, 'Ādil. "al-Dacwā ilā l-Islām fì l-gharb” [Calling for Islam in the west]. al-Fath 7, no. 308 (2 Sept. 1932).

Arslān, Shakīb. "al-Jawāb bi-sha'n al-Qadiyāniyya" [A response regarding the Qadiyaniyya]. al-Fath 7, no. 328 (19 Jan. 1933), 6-7.

Cherfils, Christian. Bonaparte et l'Islam d'après les documents français et arabes, with a foreword by Abd El-Hakim. Paris, 1914.

Clayer, Nathalie and Eric Germain, eds. Islam in Interwar Europe. London: Hurst, 2008. Cobbold, Khwaja Nazir Ahmad. Charms of Islam: A Collection of Writings of Some of the Eminent Scholars. Woking: Woking Muslim Mission \& Literary Trust, 1935.

von Ehrenfels, Baron Omar Rolf. "Ethnology and Islamic Sciences." Islamic Culture 14, no. 4 (Oct. 1940).

—. "The 'How?' and 'Why?' of Conversion to Islam." Islamic Review 49, no. 6 (June 1961).

—. "Islam and the Present Generation in Europe." Islamic Review, 20, no. 11 (Nov. 1932).

_. "Islam und Wissenschaft." Kairos: Zeitschrift für Religionswissenschaft und Theologie 5 (1963): 114 .

—. Das Kulturproblem der Entwicklungshilfe im Südasiatischen Raum. Heidelberg: Universität Heidelberg. Südasien-Institut, 1966.

-. Mother-Right in India. Hyderabad: Government Central Press, 1941.

—. "Muslim Women in Present-Day Europe." Islamic Culture 24, no. 10 (July 1936). "The Pre-Aryan Cultures of India and the Ethnological Background of Islam." Islamic Culture 13, no. 2 (April 1939).

"A Scheme for Equitable Distribution of Zakat." Islamic Review 34 (1946), 407.

Facey, William. "Mayfair to Makkah." Saudi Aramco World 59, no. 5 (2008): 18-23. Online: http://www.saudiaramcoworld.com/issue/200805/mayfair.to.makkah.htm (accessed 20 March 2014).

Germain, Eric. "The First Muslim Mission on a European Scale: Ahmadi-Lahori Networks in the Interwar Period." In Islam in Inter-War Europe, edited by Nathalie Clayer and Eric Germain. London: C. Hurst \& Co., 2008.

Ghazar, Amal N. "Power, Arabism and Islam in the Writings of Muhib ad-Din aI-Khatib in al-Fath." Past Imperfect 6 (1997): 133-150. 
Gilham, Jamie. Loyal Enemies: British Converts to Islam 1850-1950. London: Hurst, 2014.

al-Ḥamāmī, Mușțafā Abū Sayf. Ghawth al-ibād bi-bayna al-rashād. Cairo, $195^{\circ}$. al-Nahda al-islāhiyya. Cairo, 1935.

Hanson, H. "Jihad and the Ahmadiyya Muslim Community: Nonviolent Efforts to Promote Islam in the Contemporary World." Nova Religio 11, no. 2 (2007): 77-93.

Headley, Rowland George Allanson. "Why I became a Mohammedan." Observer (23 November 1913).

al-Hilālī, Muḥammad Taqī l-Dīn. "Abdullāh Daye: Akh Muslim yasqut min ṣufūf al-jihād [Abdullah Daye?: A Muslim brother fell down the rows of jihad]". al-Fath 7 , no. 325 (29 Dec. 1932a).

—. "Bal hiya rābița Qadiyāniyya" [It is a Qadiyani association], al-Fath 7, no. 340 (14 April 1933a).

. "al-Barā'a min al-Qadiyāniyya" [Clearing one's name from the Qadiyaniyya]. al-Fatḥ 8, no. 372 (23 Nov. 1933b).

- "al-Baron Omar Rolf al-Nimsāwi aslma islāman qadiyāniyyan" [The Austrian Baron Omar holds a Qadiyani Islam]. al-Fatḥ 7, no. 337 (24 March 1933c), 14.

- "Fì tarjamat al-Qur'ān ayḍan" [Regarding the translation of the Qurān, too]. al-Fath 6, no. 293 (6 April 1932b), 4-7.

. "al-Itijār bi-l-dīn" [Trading in religion]. al-Fath 8, no. 371 (16 Nov. 1932c), $9^{-12 .}$

"Khalid Sheldrake fī l-Hind: ḥadīth lahu muhim 'an al-shu'un al-Islāmiyya" [Khalid Sheldrake in India: An important talk for him about Islamic issues]. al-Fath 7, no. 326 (5 Jan. 1933d), 6-7.

_. "al-Qadiyāniyyūn-Ba`ḍu ma lahum wa-mā 'alayhim" [The Qadiyanis, the pros and cons]. al-Fath 7 , no. 315 (21 Oct. 1932d), 9-10.

—. "Sabb al-Qadiyāniyyīn li-l-Islām I \& II" [The offense of Qadiyanis to Islam I \& II ] , no. 362 (15 Sept. 1933e), 1-5 and (21 Sept. 1933), 13-16 [[in al-Fath?]] yes...

Honvault, J. "Speaking about Oneself when External Life is Ethically Primordial: The Diary of the Sryo-Lebanese Arab Nationalist 'Ādil Arslān (1887-1954)." In Many Ways of Speaking About the Self: Middle Eastern Ego-Documents in Arabic, Persian, and Turkish (14th-2oth Century), edited by Yavuz Köse and Ralf Herausgegeben von Elger. Wiesbaden: Harrassowitz, 2010.

Hurvitz, Nimrod. "Muhibb ad-Din al-Khatib's Semitic Wave Theory and Pan-Arabism." Middle Eastern Studies 29, no. 1 (1993): 118-134.

Ḥusayn, Muḥammad al-Khiḍr. "Ṭāifa al-Qadyāniyya" [A Qadiyani sect], al-Fatḥ 7, no. 317 (3 Nov. 1932), $1-7$.

Irish Times. "Moslem Funeral Service." 1 September 1928.

al-Khațīb, Muhibb al-Dīn. "Islāmuna wa-Islām al-Qadiyāniyyīn" [Our Islam and the Islam of the Qadiyanis]. al-Fath 7, no. 322 (8 Dec. 1932a): 1-3. 
—. "al-Qadiyāniyya dīn yukhālif dīn al-Islām kamā anna al-Nașraniyya dīn yukhālif dīn al-Yahūd" [Qadiyaniyya: A religion that contradicts Islam just as Christianity contradicts the religion of the Jews]. al-Fath 7 , no. 320 (24 Nov. 1932b): 1-2.

Lavan, Spencer. "Polemics and Conflict in Ahmadiyya History: The 'Ulema, the Missionaries, and the British (1898)." Muslim World 62, no. 3 (1972): 283-303.

Maḥmūd, 'Abd al-Ḥalīm. al-Hamdu li-Llāh hadhihi hayātī. Cairo: Dār al-Ma'ārif, 1985. —. Uruba wa-l-Islām. Cairo: Dār al-Ma'ārif, 1991.

Manchester Guardian. “40,00o For London Mosque.” 27 February 1928.

Manchester Guardian. "Irish Peer converted to Mohametanism." 17 November 1913.

Mayeur-Jaouen, Catherine. "Les débuts d'une revue néo-salafiste: Muhibb al-Dîn alKhatîb et Al-Fath de 1926 à 1928." Revue des mondes musulmans et de la Méditerranée 95-98 (April 2002): 227-255. Online: http://remmm.revues.org/234.

Moch Nur Ichwan. "Differing Responses to an Ahmadi Translation and Exegesis: The Holy Qur'ān in Egypt and Indonesia." Archipel 62 (2001): 143-161.

al-Nabhānī, Taqī l-Dīn. "al-Qadiyāniyya wa-l-falsafa al-hindiyya" [The Qadiyaniyya and Indian philosophy]. al-Fath 8, no. 372 (23 Nov. 1933).

New York Times. "English Moslem Peer Deplores Plane Conversion of Princess." 20 February 1932.

New York Times. "Irish Peer turns Moslem." 16 November 1913.

Observer. "Mohammedan Peer." 16 November 1913.

Rifaat, Mansur. Die Ahmadia Agenten: ein Rätsel. Werden sie tatsächlich von den deutschen Behörden unterstützt und beschützet? (Berlin: Morgen- und Abendland Verlag, 1924a).

- Ahmadi Betrayal of Country and Religion (Berlin: Morgen- und Abendland Verlag, 1923a).

- The Ahmadi Sect: Vanguard of the British Imperialism and the Greatest Danger to Islam, Convincing Evidence of their Duplicity (Berlin: Morgen- und Abendland Verlag, 1923b).

—. Die Ahmadia-Sekte: Ein Vorkämpfer für den englischen Imperialismus (Berlin, 1923c).

- Total Demoralisation of the Ahmadia Sect: Further Evidence in regard to their Activities as British Agents and Menace to Islam (Berlin: Morgen- und Abendland Verlag, 1924b).

- Der Verrat der Ahmadis an Heimat und Religion (Berlin: Morgen- und Abendland Verlag, 1923d).

—. Vollständiger Zusammenbruch der Ahmadia-Sekte: Weitere Beweise für Ihre Tätigkeit als englische Agenten (Berlin: Morgen- und Abendland Verlag, 1924c).

Ryad, Umar. Islamic Reformism and Christianity: A Critical Reading of the Works of Muhammad Rashid Rid̄a and his Associates (1898-1935). Leiden: Brill, 2009. 
"Islamic Reformism and Great Britain: Rashid Riḍā's Images as Reflected in the Journal al-Manār in Cairo." Islam and Christian Muslim Relations 21, no. 3 (2010): $263-285$.

- "From an Officer in the Ottoman Army to a Muslim Publicist and Armament Agent in Berlin: Zekî Hishmat Kirâm (1886-1946).” Bibliotheca Orientalis 63, nos. 3-4 (2006), 235-268.

Saeedullah. The Life and Works of Muhammad Siddiq Hasan Khan, Nawab of Bhopal: 1248-1307/1832-189o with a foreword by H.M. 'Abd al-Quddus Qasmi. Lahore: Sh. Muhammad Ashraf, 1973.

al-Sharīf, Aḥmad. "al-Lahūriyyūn wa-Brītania" [The Lahoris in Britian]. al-Fatḥ 9, no. 423 (29 Nov. 1934), 20-22.

Sheldrake, Khalid. "al-Duktūr Khalid Sheldrake yataḥaddath 'an tārīkh 'alāqatih bi-lIslām wa yu'lin barā’atahu min al-Aḥmadiyya wa-l-Qadyāniyya awalan wa-ākhiran" [Dr. Khalid Sheldrake speaks about the history of his relationship to Islam and clears his name from any connection with the Ahmadiyya and Qadiyaniyya]. al-Fath 8, no. 383 (15 Feb. 1934a), 6-7.

_. "Islam and the Unity of Mankind." Islamic Review 9, no. 10 (Oct. 1921a), $373-376$.

—. "Li-mādha yaḥmilu 'alayya al-Aḥmadiyyūn?" [Why are the Ahamdis against me?]. al-Fath 9, no. 421 (15 Nov. 1934b), 22-23 and al-Fath 9, no. 422 (22 Nov. 1934), 14-15.

—. "The Message to Mankind." Islamic Review 9, no. 1 (Jan. 1921b), 21-24.

- "More 'Massacres"' Islamic Review 10, nos. 6-7 (June/July 1922), 267-270.

. "Muhammad and World Unity." Islamic Review 14, nos. 3-4 (March/April 1926), $148-15^{2 .}$

—. "Mustaqbal al-Islām" [The future of Islam]. al-Fath 9, no. 434 (21 Feb. 1935a), $12-13$.

. "Our Duty To-day." Islamic Review 9, no. 2 (Feb. 1921c), 71-73.

. "Practical Experience of Islam." Islamic Review 9, no. 11 (Nov. 1921d), 420-422.

. "The Religion of Peace." Islamic Review and Muslim India 3 (1915).

"al-Yabān wa-l-Islām al-ḥaqq" [Japan and genuine Islam]. al-Fatḥ 9, no. 439 (5 April 1935b), 18-19.

Straits Times. "Head of Seven Million Muslims Visits Singapore." 26 June 1933.

Times. "British Muslims' Leader Resigns." 12 December 1935. 